\title{
Control of Serotonergic Function in Medial Prefrontal Cortex by Serotonin-2A Receptors through a Glutamate-Dependent Mechanism
}

\author{
Raúl Martín-Ruiz, ${ }^{1}$ M. Victoria Puig, ${ }^{1}$ Pau Celada, ${ }^{1}$ David A. Shapiro, ${ }^{2}$ Bryan L. Roth, ${ }^{2}$ Guadalupe Mengod, ${ }^{1}$ \\ and Francesc Artigas ${ }^{1}$ \\ 1Department of Neurochemistry, Institut d' Investigacions Biomèdiques de Barcelona (Consejo Superior de \\ Investigaciones Científicas), Institut d'Investigacions Biomèdiques August Pi i Sunyer, 08036 Barcelona, Spain, and \\ 2Departments of Biochemistry, Neurosciences and Psychiatry, Case Western Reserve University Medical School, \\ Cleveland, Ohio 44106
}

We examined the in vivo effects of the hallucinogen 4-iodo-2,5dimethoxyamphetamine (DOI). DOI suppressed the firing rate of 7 of 12 dorsal raphe (DR) serotonergic (5-HT) neurons and partially inhibited the rest $\left(E D_{50}=20 \mu \mathrm{g} / \mathrm{kg}\right.$, i.v.), an effect reversed by $\mathrm{M} 100907\left(5-\mathrm{HT}_{2 \mathrm{~A}}\right.$ antagonist) and picrotoxinin $\left(\mathrm{GABA}_{\mathrm{A}}\right.$ antagonist). DOI (1 $\mathrm{mg} / \mathrm{kg}$, s.c.) reduced the $5-\mathrm{HT}$ release in medial prefrontal cortex (mPFC) to $33 \pm 8 \%$ of baseline, an effect also antagonized by M100907. However, the local application of $\mathrm{DOI}$ in the mPFC increased 5 -HT release (164 $\pm 6 \%$ at $100 \mu \mathrm{M})$, an effect antagonized by tetrodotoxin, M100907, and BAY $\times 3702\left(5-\mathrm{HT}_{1 \mathrm{~A}}\right.$ agonist) but not by SB 242084 (5- $\mathrm{HT}_{2 \mathrm{C}}$ antagonist). The 5-HT increase was also reversed by NBQX (AMPA-KA antagonist) and 1S,3S-ACPD (mGluR 2/3 agonist) but not by MK-801 (NMDA antagonist). AMPA mimicked the 5-HT elevation produced by DOI. Likewise, the electrical-chemical stimulation of thalamocortical afferents and the local inhibition of glutamate uptake increased the 5-HT release through AMPA receptors. DOI application in MPFC increased the firing rate of a subgroup of 5-HT neurons (5 of 10), indicating an enhanced output of pyramidal neurons. Dual-label fluorescence confocal microscopic studies demonstrated colocalization of $5-\mathrm{HT}_{1 \mathrm{~A}}$ and $5-\mathrm{HT}_{2 \mathrm{~A}}$ receptors on individual cortical pyramidal neurons.

Thus, DOI reduces the activity of ascending 5-HT neurons through a DR-based action and enhances serotonergic and glutamatergic transmission in mPFC through $5-\mathrm{HT}_{2 \mathrm{~A}}$ and AMPA receptors. Because pyramidal neurons coexpress $5-\mathrm{HT}_{1 \mathrm{~A}}$ and 5- $\mathrm{HT}_{2 \mathrm{~A}}$ receptors, DOI disrupts the balance between excitatory and inhibitory inputs and leads to an increased activity that may mediate its hallucinogenic action.

Key words: 5-hydroxytryptamine; 5- $H T_{1 A}$ receptors; 5- $H T_{2 A}$ receptors; AMPA; DOI; dorsal raphe nucleus; GABA; glutamate; hallucinogens; medial prefrontal cortex; microdialysis; mGluR; NMDA; single-unit recordings; thalamus
The prefrontal cortex plays a crucial role in higher brain functions (Fuster, 1997). It receives a dense innervation from the brainstem aminergic nuclei, including the serotonergic dorsal and median raphe nuclei of the midbrain (Azmitia and Segal, 1978). The prefrontal cortex contains a very large density of $5-\mathrm{HT}_{1 \mathrm{~A}}$ and $5-\mathrm{HT}_{2 \mathrm{~A}}$ receptors located on pyramidal neurons. Likewise, GABAergic interneurons are enriched in $5-\mathrm{HT}_{2 \mathrm{~A}}$ and $5-\mathrm{HT}_{3}$ receptors (Pompeiano et al., 1992, 1994; Kia et al., 1996; Willins et al., 1997; Jakab and Goldman-Rakic, 1998, 2000). Although the exact role of serotonergic neurotransmission in prefrontal cortex remains largely unknown (Robbins, 2000) serotonergic agents acting on cortical receptors are hallucinogenic [nonselective $5-\mathrm{HT}_{2 \mathrm{~A}}$ agonists such as D-lysergic acid diethylamide-25 (LSD) or 4-iodo-2,5-dimethoxyamphetamine (DOI)] or have proven effec-

Received July 9, 2001; revised Sept. 18, 2001; accepted Sept. 26, 2001.

This work was supported by National Institutes of Health Grants FIS 01/1147 and SAF01-2133 (F.A.), KO2MH01366 and RO1MH61887 (B.L.R.), and a National Alliance for Research on Schizophrenia and Depression Young Investigator Award to D.A.S. M.V.P. is recipient of a predoctoral fellowship from the Institut d'Investigacions Biomèdiques August Pi i Sunyer. Financial support from Bayer S.A. is also acknowledged. We thank the pharmaceutical companies for the generous supply of drugs. The technical help of Leticia Campa is gratefully acknowledged. R.M.R. and M.V.P. contributed equally to this work.

Correspondence should be addressed to Dr. Francesc Artigas, Department of Neurochemistry, Institut d' Investigacions Biomèdiques de Barcelona (Consejo Superior de Investigaciones Científicas), Institut d'Investigacions Biomèdiques August Pi i Sunyer, Rosselló, 161, Sixth floor, 08036 Barcelona, Spain. E-mail: fapnqi@iibb.csic.es.

Copyright (C) 2001 Society for Neuroscience $\quad 0270-6474 / 01 / 219856-11 \$ 15.00 / 0$ tive in the treatment of depression and schizophrenia (5-HT uptake inhibitors, 5- $\mathrm{HT}_{1 \mathrm{~A}}$ agonists/5- $\mathrm{HT}_{2 \mathrm{~A}}$ antagonists) (Kroeze and Roth, 1998; Meltzer, 1999).

5-HT exerts complex actions on pyramidal neurons of the medial prefrontal cortex (mPFC). Previous work showed that 5-HT hyperpolarizes and depolarizes layer V pyramidal neurons by acting on $5-\mathrm{HT}_{1 \mathrm{~A}}$ and $5-\mathrm{HT}_{2}$ receptors, respectively (Araneda and Andrade, 1991), although no direct anatomical evidence for the colocalization of both receptors on individual pyramidal neurons has thus far been presented. More recently, Aghajanian and Marek (1997) demonstrated that the focal application of 5-HT on apical dendrites of pyramidal neurons in the mPFC evoked EPSCs by a $5-\mathrm{HT}_{2 \mathrm{~A}}$ receptor-dependent mechanism. Likewise, the hallucinogen DOI, a partial $5-\mathrm{HT}_{2 \mathrm{~A} / 2 \mathrm{C}}$ receptor agonist, enhanced late EPSCs evoked by the electrical stimulation of afferent fibers (Aghajanian and Marek, 1999a). These effects are most likely mediated by a release of glutamate, triggered by the activation of $5-\mathrm{HT}_{2 \mathrm{~A}}$ receptors, and the subsequent activation of AMPA receptors (Aghajanian and Marek, 1997, 1999a,b).

The apparent presence of $5-\mathrm{HT}_{1 \mathrm{~A}}$ and $5-\mathrm{HT}_{2 \mathrm{~A}}$ receptors in layer $\mathrm{V}$ pyramidal neurons suggests that they could be involved in the control of subcortical structures. The mPFC is one of the few forebrain areas projecting densely to the serotonergic dorsal raphe nucleus (DR) (Aghajanian and Wang, 1977; Sesack et al., 1989; Hajós et al., 1998; Peyron et al., 1998). Additionally, the electrical stimulation of the mPFC modulates the activity of 5-HT 
neurons in a complex manner (Hajós et al., 1998; Celada et al., 2001). Moreover, the activation of postsynaptic $5-\mathrm{HT}_{1 \mathrm{~A}}$ receptors in the mPFC reduced the local release of 5-HT (Casanovas et al., 1999) and the firing rate of dorsal raphe 5-HT neurons (Celada et al., 2001). These data suggest that pyramidal neurons containing $5-\mathrm{HT}_{1 \mathrm{~A}}$ receptors may participate in the distal control of serotonergic activity. Because $5-\mathrm{HT}_{1 \mathrm{~A}}$ and $5-\mathrm{HT}_{2 \mathrm{~A}}$ receptors may colocalize in layer $\mathrm{V}$ pyramidal neurons projecting to the $\mathrm{DR}$, $5-\mathrm{HT}_{2 \mathrm{~A}}$ receptors could be involved in this control. Therefore, in the present study we examined the actions of the hallucinogen DOI, a $5-\mathrm{HT}_{2 \mathrm{~A} / 2 \mathrm{C}}$ agonist, on the serotonergic system using in vivo microdialysis and single-unit recordings. The results obtained indicate that $5-\mathrm{HT}_{2 \mathrm{~A}}$ receptor activation has profound effects on serotonergic neurons, likely via an enhancement of the AMPAmediated neurotransmission in medial prefrontal cortex.

\section{MATERIALS AND METHODS}

Animals. Male albino Wistar rats (Iffa Credo, Lyon, France) weighing 280-320 gm and kept in a controlled environment ( $12 \mathrm{hr}$ light/dark cycle and $22 \pm 2^{\circ} \mathrm{C}$ room temperature) with food and water provided ad libitum, were used in in vivo experiments. Animal care followed the European Union regulations (O.J. of E.C. L358/1 18/12/1986).

Drugs and reagents. 5-HT oxalate, 8-hydroxy-2-(di- $n$-propylamino)tetralin (8-OH-DPAT), $\alpha$-amino-3-hydroxy-5-methyli-4-soxazole-4-propionate $[(S)$ AMPA],bicuculline, cyclothiazide, 1-[2,5-dimethoxy-4-iodophenyl-2-aminopropane (DOI), L-trans-pyrrolidine-2,4-dicarboxylic acid (L-trans-PDC), (+)MK-801 (dizolcipine), NBQX, 2,3-dihydroxy-6-nitro-7-sulfamoylbenzo(f)quinoxaline, picrotoxininin, 6-chloro-5-methyl-1-[6-(2-methylpyridin-3-yloxy) pyridin-3-yl carbamoyl] indoline (SB 242084), tetrodotoxin (TTX), and $N$-(2-(4-(2-methoxyphenyl)-1-piperazinyl)ethyl)- $N$-(2-pyridyl) cyclohexanecarboxamide - 3HCl (WAY-100635), were from Sigma/Research Biochemicals (Natick, MA). 1S,3S-aminecyclopentane dicarboxylic acid $(1 S, 3 S$-ACPD) was from Tocris (Bristol, UK). BAY $\times 3702,\{R-(-)-$ 2-237 4-[(chroman-2-ylmethyl)-amino]-butyl 253-1,1-dioxo-benzo[d] isothiazolone $\cdot \mathrm{HCl}\}$, citalopram $\cdot \mathrm{HBr}, \mathrm{LY} 379268$ \{(-)-2-oxa-4-aminobicyclo[3.1.0]hexane-4,6-dicarboxylate]\}, and M100907 [R-(+)- $\alpha$-(2,3-dimethoxyphenil)-1-[4-fluorophenylethyl]-4-piperidinemethanol] were from Bayer AG, Lundbeck A/S, Eli Lilly \& Co. (Indianapolis, IN), and Marion Merrel Dow (Strasbourg, France), respectively. A mouse monoclonal $5-\mathrm{HT}_{2 \mathrm{~A}}$ antibody and a guinea pig polyclonal $5-\mathrm{HT}_{1 \mathrm{~A}}$ antibody were obtained from PharMingen (San Diego, CA). Other materials and reagents were from local commercial sources. For the assessment of local effects, drugs were dissolved in the perfusion fluid and applied by reverse dialysis at the stated concentrations. Concentrated solutions ( $1 \mathrm{~mm}$; $\mathrm{pH}$ adjusted to $6.5-7$ with $\mathrm{NaHCO}_{3}$ when necessary) were stored frozen $\left(-80^{\circ} \mathrm{C}\right)$, and working solutions were prepared daily by dilution. Concentrations are expressed as free bases. Control rats were perfused for the entire experiment with artificial CSF. The bars in the figures show the period of drug application (corrected for the void volume of the system). In experiments involving systemic administration, the drugs were administered subcutaneously or intravenously at the doses stated.

Surgery and microdialysis procedures. An updated description of the microdialysis procedures used can be found in Adell and Artigas (1998). Briefly, anesthetized rats (pentobarbital; $60 \mathrm{mg} / \mathrm{kg}$, i.p.) were stereotaxically implanted with one concentric microdialysis probe equipped with a Cuprophan membrane in medial prefrontal cortex [anteroposterior (AP) +3.4, lateral (L) -0.8, dorsoventral (DV) -6.0; probe tip: $4 \mathrm{~mm}$ ] (coordinates in millimeters; Paxinos and Watson, 1986). On the next day, microdialysis experiments were performed in freely moving rats. The probes were perfused at $1.5 \mu \mathrm{l} / \mathrm{min}$ with artificial CSF (aCSF) (in mM: $125 \mathrm{NaCl}, 2.5 \mathrm{KCl}, 1.26 \mathrm{CaCl}_{2}$, and $1.18 \mathrm{MgCl}_{2}$ ) containing $1 \mu \mathrm{M}$ citalopram. After a $1 \mathrm{hr}$ stabilization period, four fractions were collected to obtain basal values before local (reverse dialysis) or systemic administration of drugs. Successive $20 \mathrm{~min}(30 \mu \mathrm{l})$ dialysate samples were collected. In most experiments, the partial $5-\mathrm{HT}_{2 \mathrm{~A} / 2 \mathrm{C}}$ receptor agonist DOI was applied alone for $2 \mathrm{hr}$ (six fractions). This was followed by the application of DOI in combination with other drugs for another $2 \mathrm{hr}$ period. In experiments assessing the effect of L-trans-PDC on 5-HT release, the drug was perfused alone or in combination with other agents for $2 \mathrm{hr}$ after collection of baseline values.

Three microdialysis experiments were conducted in chloral hydrateanesthetized animals. In one of them, we examined the effect of the electrical stimulation of the midline thalamus projecting to $\mathrm{mPFC}$, to modulate the release of 5-HT in the latter area. Microdialysis probes were implanted as above. Stimulating bipolar electrodes were used. The isolating material was peeled off $\sim 1 \mathrm{~mm}$ above the tip, the poles were separated $100-150 \mu \mathrm{m}$, and electrodes were stereotaxically placed and secured with dental cement, as for microdialysis probes. The tip of the electrodes was aimed at the top part of the centromedial thalamic nucleus (AP -3.6, L -0.7, DV -6.5). In this manner, the stimulated area was between DV -6.5 and DV -5.5 , thus affecting the mediodorsal nucleus and part of the centromedial nucleus (plate 32; Paxinos and Watson, 1986). The lesion of this thalamic area has been shown to attenuate the EPSCs induced by 5-HT in layer V mPFC pyramidal neurons (Marek et al., 2001). On the next day, rats were anesthetized with chloral hydrate as in single-unit recording experiments (see below). After a $2 \mathrm{hr}$ stabilization period, electrical stimulation was performed $(5 \mathrm{~Hz}, 1.5 \mathrm{~mA}, 0.3 \mathrm{msec}$ square pulses) for 20 min with a Grass S-48 stimulator unit S-48 connected to a Grass SIU isolation unit, and dialysate fractions were collected for one more hour. In some rats, the stimulating electrode was implanted, but no current was passed.

The second experiment examined the effects of the application of bicuculline in the midline thalamus (to disinhibit afferent fibers to $\mathrm{mPFC}$ ) on the 5-HT release in mPFC. These rats were implanted with two dialysis probes, in mPFC (as above) and in the thalamus (coordinates: AP $-3.2, \mathrm{~L}-0.5$, DV -6.5 ; probe tip, $1.5 \mathrm{~mm}$ ). In this location, the administration of bicuculline by reverse dialysis through the thalamic probe was also intended to affect both the centromedial and mediodorsal thalamic nuclei. The third experiment assessed the effects of the systemic administration of DOI $(1 \mathrm{mg} / \mathrm{kg}$, s.c. $)$ on 5 -HT release in the mPFC of chloral hydrate-anesthetized rats, to mimic the experimental conditions of single-unit recordings. At the end of the experiments, rats were killed by an overdose of sodium pentobarbital. The placement of the dialysis probes was examined by perfusion of Fast green dye and visual inspection of the probe track after cutting the brain at the appropriate levels. In experiments involving the electrical or chemical stimulation of thalamic afferents to $\mathrm{mPFC}$, the placement of the thalamic probes or electrodes was verified histologically with Neutral Red staining.

The concentration of 5-HT in dialysate samples was determined by HPLC, as described (Adell and Artigas, 1998). 5-HT was separated using a Beckman (San Ramon, CA) $3 \mu \mathrm{m}$ particle size column and detected with a Hewlett Packard 1049 electrochemical detector at +0.6 V. Retention time was between 3.5 and $4 \mathrm{~min}$, and the limit of detection was typically $1 \mathrm{fmol} / \mathrm{sample}$.

Single-unit recordings. We examined the effect of the systemic administration of DOI on the firing activity of identified 5-HT neurons in the dorsal raphe nucleus (DR). Single-unit extracellular recordings were performed as previously described (Sawyer et al., 1985; Celada et al., 1996). Briefly, rats were anesthetized (chloral hydrate, $400 \mathrm{mg} / \mathrm{kg}$, i.p.) and positioned in a stereotaxic apparatus. Additional doses of chloral hydrate $(80 \mathrm{mg} / \mathrm{kg})$ were administered intravenously. Body temperature was maintained at $37^{\circ} \mathrm{C}$ throughout the experiment with a heating pad. All wound margins and points of contact between the animal and the stereotaxic apparatus were infiltrated with lidocaine solution $(5 \%)$. To minimize pulsation, the atlanto-occipital membrane was punctured to release some CSF. For recordings in the DR, a burr hole of $\sim 4 \times 4 \mathrm{~mm}$ was drilled over lambda, and the sagittal sinus was ligated, cut, and reflected. Single units in the DR were recorded extracellularly with glass micropipettes pulled from $2.0 \mathrm{~mm}$ capillary glass (World Precision Instruments, Sarasota, FL) on a Narishige (Tokyo, Japan) PE-2 pipette puller. Microelectrodes were filled with $2 \mathrm{M} \mathrm{NaCl}$. Typically, impedance was between 4 and $10 \mathrm{M} \Omega$. Descents were performed along the midline. Recorded 5-HT neurons were found $5.0-5.8 \mathrm{~mm}$ below the brain surface and were identified according to previously described electrophysiological criteria (Wang and Aghajanian, 1977). They exhibited a regular spontaneous firing rate with frequencies from 0.4 to $2.2 \mathrm{~Hz}$, and 2-5 msec biphasic or triphasic extracellular waveform.

Single-unit potentials were amplified with a Neurodata IR283 (Cygnus Technology Inc., Delaware Water Gap, PA), postamplified, and filtered with a Cibertec amplifier (Madrid, Spain) and computed on-line using a DAT 1401plus interface system Spike2 software (Cambridge Electronic Design, Cambridge, UK). After recording stable baseline spontaneous activity for at least $5 \mathrm{~min}$, DOI was administered $(0.025-0.4 \mathrm{mg} / \mathrm{kg}$, i.v.; cumulative doses) every 2 min. Once a maximal effect of DOI was attained, either M100907 (100 $\mu \mathrm{g} / \mathrm{kg}$, i.v.; Haddjeri et al., 1999) or the $\mathrm{GABA}_{\mathrm{A}}$ receptor antagonist picrotoxinin $(1 \mathrm{mg} / \mathrm{kg}$, i.v. $)$ were injected. In some neurons, 8-OH-DPAT and WAY $100635,5-\mathrm{HT}_{1 \mathrm{~A}}$ receptor agonist 
and antagonist, respectively, were injected after M100907 or picrotoxinin to further confirm the serotonergic identity of the recorded cell. Only one neuron per rat was recorded.

Additional experiments were performed to examine the effects of the local application of DOI in mPFC on the firing rate of 5-HT neurons in the DR. DOI $(200 \mu \mathrm{M}$, dissolved in aCSF) was infused through a 32 gauge stainless steel cannula (Small Parts Inc., Miami, FL) implanted in the mPFC (tip coordinates: AP $+3.4, \mathrm{~L}-0.8, \mathrm{DV}-4.5$ ). The cannula was attached to a $10 \mu \mathrm{l}$ Hamilton syringe by a Teflon tubing. A microinfusion pump (Bioanalytical Systems Inc., West Lafayette, IN) was used. After recording baseline spontaneous activity for at least $5 \mathrm{~min}, 200$ $\mathrm{nl}$ of DOI was infused over the course of $1 \mathrm{~min}$. This volume has been reported to diffuse to a maximum effective diameter of $0.4-0.6 \mathrm{~mm}$ (Myers, 1971). In some rats, a second DOI infusion was administered 5 min later.

Data and statistical analysis. Microdialysis results are expressed as femtomoles per fraction (uncorrected for recovery) and shown in figures as percentages of basal values (individual means of four predrug fractions). Statistical analysis of drug effects on dialysate 5-HT was performed using one- or two-way ANOVA for repeated measures of raw data with time as repeated factor and dose or pretreatment as independent factor. The effects of drugs or chemical stimulation on the 5-HT output were analyzed by one- or two-way ANOVA of raw data followed by post hoc Duncan test. Changes in firing rate were quantified by averaging the values in the second minute after drug injection and expressed as percentage of baseline. $\mathrm{ED}_{50}$ values were calculated with the GraphPad (San Diego, CA) Prism program. Data are expressed as the mean \pm SEM. Statistical significance has been set at the $95 \%$ confidence level (two-tailed).

Cell culture and monoclonal antibody production. Stably transfected Chinese Hamster Ovary $(\mathrm{CHO})$ cells expressing the $5-\mathrm{HT}_{1 \mathrm{~A}}$ receptor were obtained from J. Raymond (Medical University of South Carolina, Charleston, $\mathrm{SC}$ ). A monoclonal 5- $\mathrm{HT}_{1 \mathrm{~A}}$ receptor antibody was prepared as follows. Female BALB/c mice were immunized intraperitoneally with $50 \mu \mathrm{g}$ of a synthetic peptide (NKRTPRRAAALISLC) conjugated to Limulus polyphemus hemocyanin and emulsified in Freund's adjuvant. Immune spleens were harvested after $\sim 3$ months and fused with SP2/0 myeloma cells at a ratio of four spleen cells per myeloma using phenylethyleneglycol. Antibody-producing colonies were detected by ELISA as follows: immunizing peptide conjugated to BSA $(10 \mu \mathrm{g} / \mathrm{ml})$ was immobilized to COSTAR 9017 EIA/RIA plates in $100 \mu$ l of coating buffer (50 $\mathrm{mm}$ carbonate-bicarbonate, $\mathrm{pH}$ 9.6) and incubated overnight at room temperature. Wells were blocked with $2 \%$ milk in PBS (blocking buffer) $1 \mathrm{hr}$, followed by addition of antibody in culture supernatant or in blocking buffer for $90 \mathrm{~min}$. Antibodies were detected using a horse anti-mouse polyclonal antibody linked to horseradish peroxidase (Vector Laboratories, Burlingame, CA; 1:2000 in blocking buffer) followed by spectrophotometric detection at $405 \mathrm{~nm}$ using the 2,2'-azino-bis(3ethylbenzthiazoline-6-sulfonic acid) substrate system (Sigma, St. Louis, $\mathrm{MO})$. Hybridomas were subjected to three rounds of limiting dilution cloning, after which antibody was produced in bulk by generation of ascites in histocompatible mice. Immunoreactivity of the antibodies was confirmed both by ELISA (as described above) and by immunohistochemical staining using $\mathrm{CHO}$ cells (control) or CHO cells stably expressing the $5-\mathrm{HT}_{1 \mathrm{~A}}$ receptor. Briefly, cells on microscope coverslips in 24 well microtiter plates were serum-starved overnight at $37^{\circ} \mathrm{C}$ and $5 \% \mathrm{CO}_{2}$, then fixed in $4 \%$ paraformaldehyde and maintained at room temperature. Cells were permeabilized 20 min with $0.1 \%$ Triton $\mathrm{X}-100$ and blocked with $2 \%$ milk for $1 \mathrm{hr}$. Anti-5-HT $1 \mathrm{~A}$ antibody supernatants were incubated with the cells for $90 \mathrm{~min}$, followed by incubation for $1 \mathrm{hr}$ with a Texas Red-labeled goat anti-mouse secondary reagent (Vector Laboratories). Cells were then mounted for confocal microscopy as previously described (Willins et al., 1997, 1999).

Confocal immunofluorescence studies. Rats were prepared for immunofluorescence studies as previously detailed (Willins et al., 1997, 1999), and free-floating $40 \mu \mathrm{m}$ sections of $\mathrm{mPFC}$ were prepared as described previously (Willins et al., 1997, 1999). Free-floating sections were then incubated in blocking buffer (PBS containing 0.2\% Triton X-100, 5\% nonfat dry milk, and $1 \%$ goat serum) for $1 \mathrm{hr}$ at room temperature. Sections were then incubated for $1 \mathrm{hr}$ at room temperature with a 1:3000 dilution of polyclonal $5-\mathrm{HT}_{2 \mathrm{~A}}$-selective antibody (Berry et al., 1996) and a 1:10 dilution of a monoclonal $5-\mathrm{HT}_{1 \mathrm{~A}}$ antibody in blocking buffer. Additional sections were incubated with a commercial monoclonal $5-\mathrm{HT}_{2 \mathrm{~A}}$ receptor antibody (1:500; PharMingen) and a commercial guinea pig polyclonal $5-\mathrm{HT}_{1 \mathrm{~A}}$ receptor antibody (1:2000; PharMingen). Sections
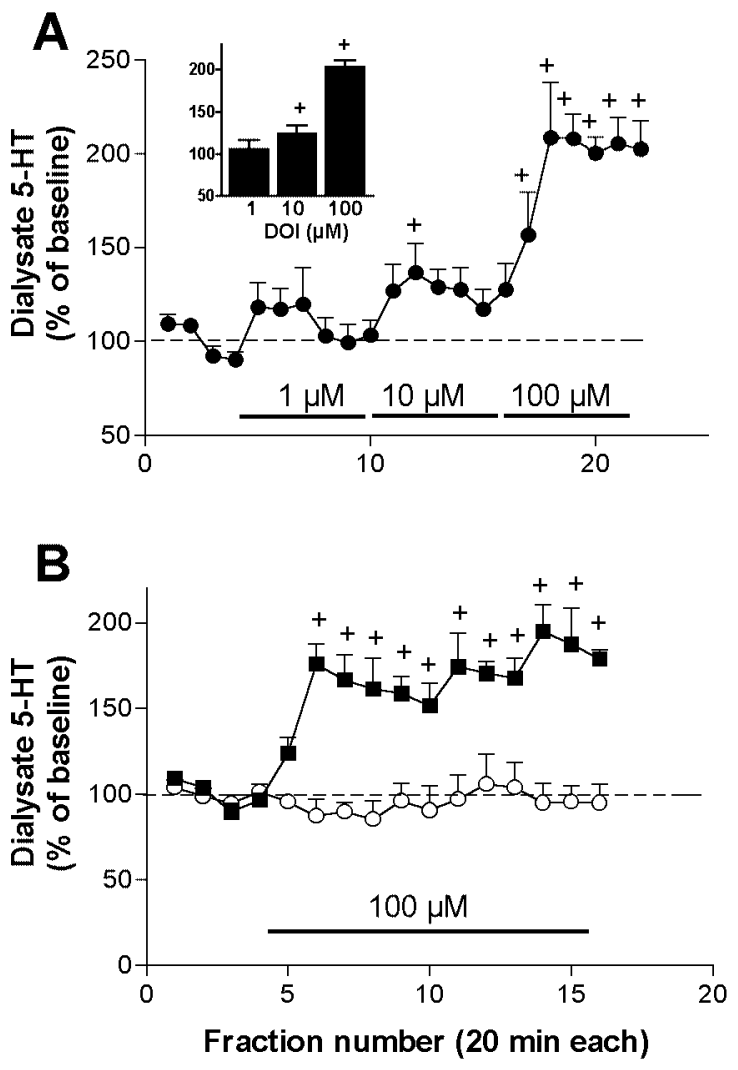

Figure 1. A, Concentration-dependent increase of 5-HT in dialysates from medial prefrontal cortex evoked by the local application of 1,10 , and $100 \mu \mathrm{M}$ of the partial $5-\mathrm{HT}_{2 \mathrm{~A} / 2 \mathrm{C}}$ receptor agonist DOI ( filled circles; $n=$ $5)$. The bar graph in the inset shows the average increase in 5-HT obtained from the last four (stabilized) fractions at each DOI concentration $\left({ }^{+} p<\right.$ 0.05 vs baseline). $B$, Effect of the continuous application of $100 \mu \mathrm{M}$ DOI ( filled squares; $n=7)$. Control rats $(n=6)$ received artificial CSF throughout the experiment. Bars show the period of drug application. ${ }^{+} p<0.05$ versus baseline; Duncan test post-ANOVA.

were then incubated overnight at $4^{\circ} \mathrm{C}$ with constant agitation. After extensive washing with PBS, sections were incubated with a 1:200 dilution of secondary antibodies (BODIPY-FL-anti-mouse and Texas Red anti-rabbit or Texas Red anti-guinea pig) for $1 \mathrm{hr}$ at room temperature followed by extensive washing with PBS and mounting for confocal microscopy as previously detailed (Willins et al., 1997, 1999). Controls included incubation of sections with secondary antibody alone.

Dual-label confocal microscopy was performed using a Zeiss Model 410 confocal microscope as previously described (Willins et al., 1997, 1999), and images were processed using Adobe Photoshop.

\section{RESULTS}

\section{Baseline 5-HT values}

The basal concentration of 5-HT in dialysates from medial prefrontal cortex was $17.5 \pm 0.8 \mathrm{fmol} /$ fraction $(n=105)$ in freely moving rats and $17.0 \pm 1.1 \mathrm{fmol} /$ fraction $(n=24)$ in chloral hydrate-anesthetized rats.

\section{Effects of the local application of DOI in medial prefrontal cortex}

The local application of 1, 10, and $100 \mu \mathrm{M}$ DOI ( $2 \mathrm{hr}$ each) increased the 5-HT output in a concentration-dependent manner. Maximal increases at each concentration were, respectively $119 \pm$ 20, $137 \pm 16$, and $209 \pm 29 \%$ of baseline $(n=5)$ (Fig. $1 A)$. One-way ANOVA showed a significant effect of DOI application $(p<0.00001)$. In subsequent experiments, we used the concentration of DOI that elicited maximal effects $(100 \mu \mathrm{M})$. 


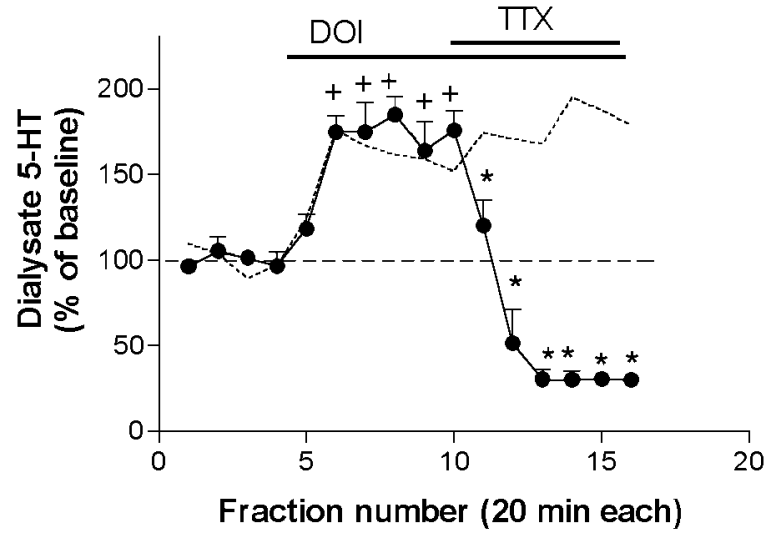

Figure 2. The perfusion of tetrodotoxin (TTX; $1 \mu \mathrm{M})$ reversed the increase in 5-HT output induced by the local application of DOI $100 \mu \mathrm{M}$ $(n=4)$. Bars show the period of drug application. The effect of DOI alone is shown by a dotted line. ${ }^{+} p<0.05$ versus baseline (DOI alone); ${ }^{*} p<0.05$ versus DOI alone (DOI + drug); Duncan test post-ANOVA.

The perfusion of $100 \mu \mathrm{M}$ DOI $(n=7)$ significantly increased the 5-HT output when compared with the control group (artificial CSF; $n=7)(p<0.02$, treatment effect; $p<0.00001$, time effect; $p<0.00001$ time $\times$ treatment interaction) (Fig. $1 B$ ). Maximally elevated 5-HT values were observed soon (40 min) after DOI application and remained elevated over the entire period of application. The mean increase produced by $100 \mu \mathrm{M}$ DOI in all perfusion experiments was $164 \pm 6 \%$ of baseline (average of fractions $7-10 ; n=69$ ).

The effect of DOI was completely antagonized by the coperfusion of $1 \mu \mathrm{M}$ TTX, which reduced 5-HT values below baseline (from $185 \pm 10$ to $30 \pm 6 \%$ of baseline; $n=4 ; p<0.00001$ ) (Fig. $2)$. Likewise, the 5 -HT increase produced by $100 \mu \mathrm{M}$ DOI was significantly attenuated by the coperfusion of $100 \mu \mathrm{M}$ of the selective $5-\mathrm{HT}_{2 \mathrm{~A}}$ receptor antagonist M100907 (DOI: $181 \pm 8 \%$ of baseline; DOI + M100907: $119 \pm 13 \%$ of baseline; $n=8 ; p<$ $0.00001)$ (Fig. $3 A)$. A higher M100907 concentration $(300 \mu \mathrm{M})$ elicited a greater reduction of the 5 -HT output (from $163 \pm 1 \%$ to $42 \pm 6 \%$ of baseline, $n=6 ; p<0.00001$ ) (Fig. $3 A$ ). In contrast, the selective $5-\mathrm{HT}_{2 \mathrm{C}}$ receptor antagonist SB 242084 did not reverse the 5 -HT elevation produced by DOI and increased the 5 -HT output further, from $178 \pm 22 \%$ to $224 \pm 25 \%$ of baseline $(n=6 ; p<0.00001)$ (Fig. $3 B)$.

The perfusion of the noncompetitive NMDA receptor antagonist MK-801 $(300 \mu \mathrm{M})$ did not significantly modify the effect of DOI $(n=7)$ (Fig. $4 A$ ). In contrast, the application of the AMPA-KA receptor antagonist NBQX $(300 \mu \mathrm{M})$ significantly reduced the effect of DOI (from $182 \pm 15 \%$ to $122 \pm 13 \%$ of baseline; $n=6 ; p<0.00001$ ) (Fig. $4 B$ ). The perfusion of the preferential mGluR $2 / 3$ agonist $1 S, 3 S$-ACPD $(300 \mu \mathrm{M})$ modestly reversed the effect of DOI on 5-HT output only in the last two fractions $(n=5 ; p<0.00001)$ (Fig. $4 C$ ). A higher concentration of $1 S, 3 S$-ACPD (1 mM) elicited a more marked antagonism and almost completely reversed the effect of DOI, from $190 \pm 15$ to $112 \pm 6 \%$ of baseline $(n=5 ; p<0.00001)$ (Fig. $4 C)$. In contrast, the application of the selective mGluR 2/3 agonist LY 379268, perfused at three different concentrations $(300 \mu \mathrm{M}, 1 \mathrm{~mm}$, and 3 $\mathrm{mM}$ ) failed to significantly reduce the 5 -HT increase induced by the local application of DOI. The average effect of LY 379268 was $96 \pm 16,97 \pm 12$, and $107 \pm 10 \%$ at $300 \mu \mathrm{M}, 1 \mathrm{~mm}$, and $3 \mathrm{~mm}$, respectively ( $n=4-5$, data expressed as percentage of the 5-HT
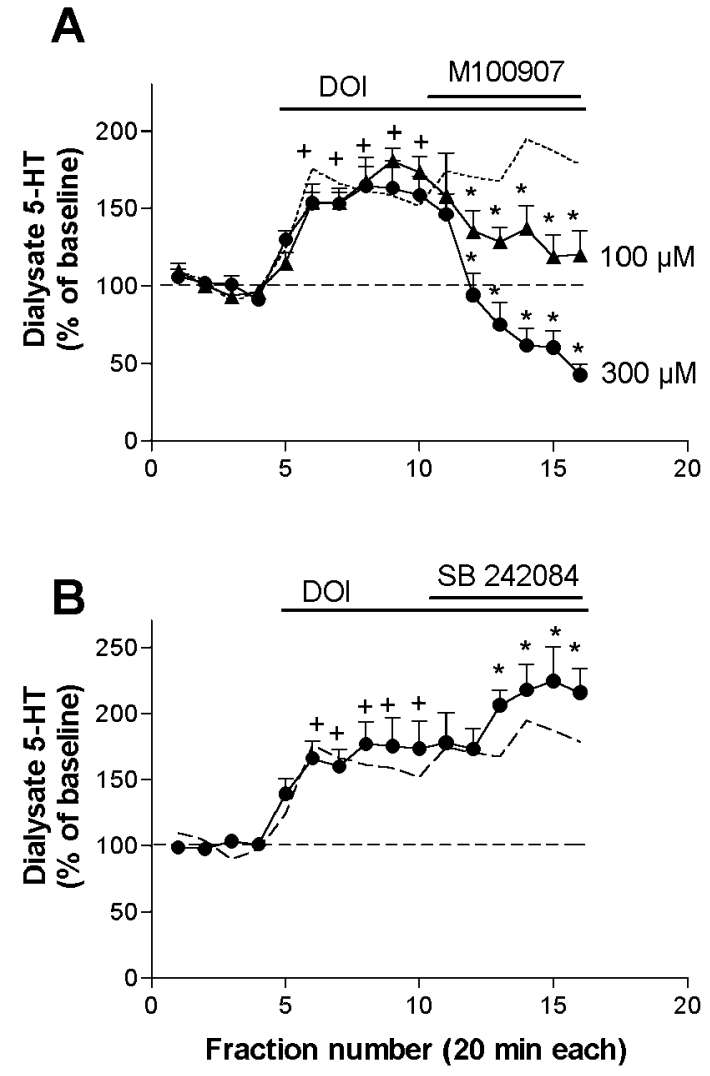

Figure 3. A, The application of the selective $5-\mathrm{HT}_{2 \mathrm{~A}}$ receptor antagonist M100907 (100 and $300 \mu \mathrm{M}$; filled triangles and circles, $n=8$ and 4, respectively) antagonized the increase in 5-HT output induced by the local application of DOI $100 \mu \mathrm{M}$. B, Lack of antagonism of the effect of DOI by the selective 5-HT 2 receptor antagonist SB $242084(100 \mu \mathrm{M}$; filled circles, $n=6$ ). This drug significantly potentiated the 5-HT increase elicited by DOI (shown by a dotted line). ${ }^{+} p<0.05$ versus baseline (DOI alone); ${ }^{*} p<0.05$ versus DOI alone (DOI + drug); Duncan test post-ANOVA.

values during DOI alone). The effect of DOI was mimicked by the local application of AMPA $(300 \mu \mathrm{M})$, which induced a maximal elevation of 5 -HT to $188 \pm 15 \%$ of baseline $(p<0.001$, treatment effect; $p<0.00001$, time effect; $p<0.00001$, time $\times$ treatment interaction compared with controls; $n=6$ ) (Fig. 4D).

The increase in 5-HT output produced by the application of DOI was strongly antagonized by the coperfusion of the selective $5-\mathrm{HT}_{1 \mathrm{~A}}$ receptor agonist BAY $\times 3702$ (De Vry et al., 1998; Casanovas et al., 2000) $(30 \mu \mathrm{M}$; from $189 \pm 30$ to $60 \pm 13 \%$ of baseline; $n=5$; $p<0.00001$ ) (Fig. 5).

\section{Localization of $5-\mathrm{HT}_{1 \mathrm{~A}}$ and $5-\mathrm{HT}_{2 \mathrm{~A}}$ receptors on individual $\mathrm{mPFC}$ pyramidal neurons}

The opposite effects of 5- $\mathrm{HT}_{1 \mathrm{~A}}$ and $5-\mathrm{HT}_{2 \mathrm{~A}}$ receptor activation in $\mathrm{mPFC}$ on 5 -HT release are in keeping with previous data on pyramidal neuron excitability (Araneda and Andrade, 1991). However, despite abundant literature on the localization of either type in cortical neurons (see introductory remarks), it is unclear whether both receptors are coexpressed in pyramidal neurons. To address this question, we prepared a monoclonal $5-\mathrm{HT}_{1 \mathrm{~A}}$ receptor antibody suitable for immunochemical studies. In preliminary studies (D. A. Shapiro and B. L. Roth, unpublished observations) we observed that the monoclonal $5-\mathrm{HT}_{1 \mathrm{~A}}$ receptor antibody specifically labeled $5-\mathrm{HT}_{1 \mathrm{~A}}$ receptors stably expressed in $\mathrm{CHO}$ cells but did not visualize untransfected $\mathrm{CHO}$ cells. As shown in 

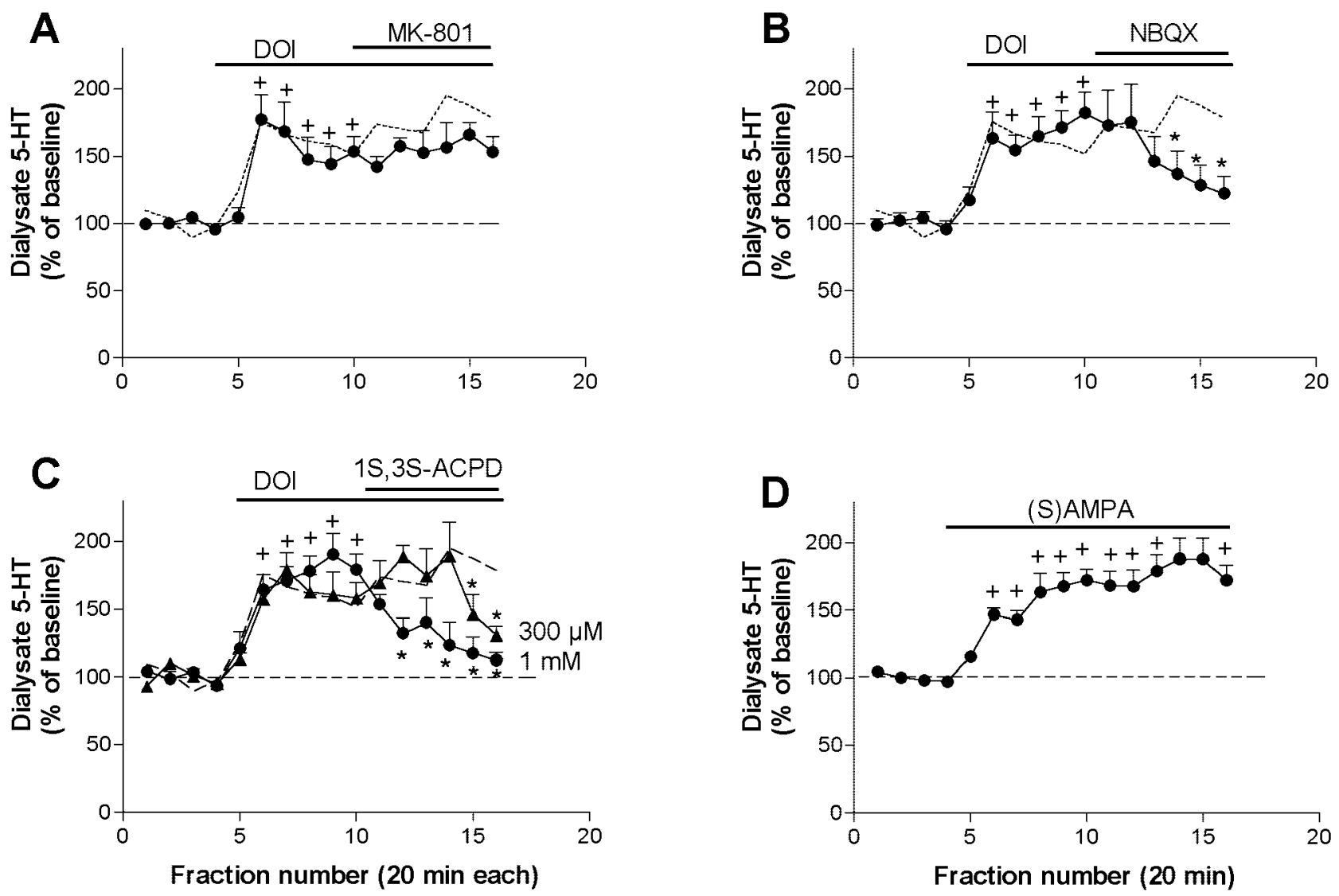

Figure 4. A, The application of the noncompetitive NMDA receptor antagonist MK-801 (300 $\mu \mathrm{M})$ did not reverse the increase in 5-HT output induced by DOI $100 \mu \mathrm{M}(n=7)$. B, Antagonism by the AMPA-KA antagonist NBQX (300 $\mu \mathrm{M})$ of the effect of DOI $(n=7)$. $C$, The mGluR 2/3 agonist $1 S, 3 S$-ACPD (300 $\mu \mathrm{M}$, filled triangles; $1 \mathrm{mM}$, filled circles; $n=5$ each) reversed the 5-HT elevation induced by DOI. $D$, The perfusion of $300 \mu \mathrm{M}$ AMPA elevated the 5-HT similarly to DOI ( $n=6$; filled circles). The effect of DOI alone is shown by a dotted line. ${ }^{+} p<0.05$ versus baseline (DOI or AMPA); ${ }^{*} p<0.05$ versus DOI alone (DOI + drug); Duncan test post-ANOVA.

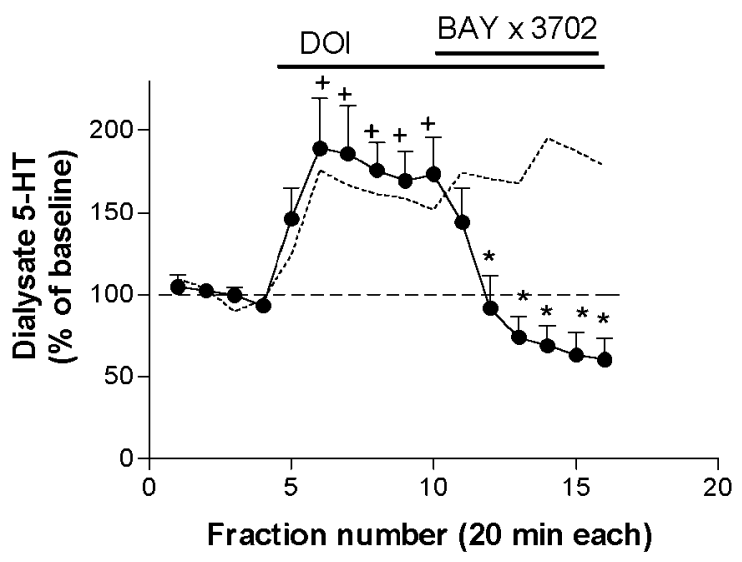

Figure 5. The selective $5-\mathrm{HT}_{1 \mathrm{~A}}$ receptor agonist $\mathrm{BAY} \times 3702(30 \mu \mathrm{M})$ reversed the DOI-induced increase in 5-HT output $(n=5)$. The effect of DOI alone is shown by a dotted line. ${ }^{+} p<0.05$ versus baseline (DOI alone); ${ }^{*} p<0.05$ versus DOI alone (DOI + drug); Duncan test post-ANOVA.

Figure $6 A-F, 5-\mathrm{HT}_{1 \mathrm{~A}}$ and $5-\mathrm{HT}_{2 \mathrm{~A}}$ receptors were abundantly colocalized on individual mPFC pyramidal neurons. Control experiments using secondary antibodies alone showed no specific immunofluorescence (Fig. 6I). Additional studies using commercially available antibodies directed against distinct epitopes of the $5-\mathrm{HT}_{1 \mathrm{~A}}$ and $5-\mathrm{HT}_{2 \mathrm{~A}}$ receptors (Fig. $6 G, H$ ) also showed extensive colocalization of $5-\mathrm{HT}_{1 \mathrm{~A}}$ and $5-\mathrm{HT}_{2 \mathrm{~A}}$ receptors in individual cortical pyramidal neurons.

\section{Effects of increased glutamatergic transmission in mPFC on serotonergic function}

The above microdialysis results suggested that DOI increased 5-HT release in $\mathrm{mPFC}$ indirectly, possibly by (1) enhancing a glutamatergic tone on 5-HT nerve terminals (local effect) and/or (2) by enhancing the activity of ascending 5-HT neurons in the DR through descending excitatory inputs. We therefore examined the effects of directly increasing the glutamatergic activity in $\mathrm{mPFC}$ on the local 5-HT release.

We first studied whether the 5-HT-increasing effects of DOI could be mimicked by endogenous glutamate. To this end, we electrically stimulated the mediodorsal and centromedial thalamic nuclei $(5 \mathrm{~Hz}, 1.5 \mathrm{~mA}, 0.3 \mathrm{msec})$ for $20 \mathrm{~min}$ and collected dialysate fractions from the ipsilateral mPFC. The electrical stimulation of these nuclei elevated the 5-HT output in mPFC to a maximum of $179 \pm 31 \%$ of baseline $(p<0.00001 ; n=6)$ (Fig. $7 A)$. Sham stimulation did not alter 5-HT levels $(n=6)$ (Fig. $7 A)$. Likewise, in dual probe microdialysis experiments, the application of bicuculline ( $300 \mu \mathrm{M}$ and $1 \mathrm{~mm})$ by reverse dialysis in the mediodorsal and centromedial thalamic nuclei doubled the 5-HT release in $\operatorname{mPFC}(n=8 ; p<0.0007)$ (Fig. $7 B)$.

Moreover, the local (in mPFC) application of the glutamate uptake inhibitor L-trans-PDC markedly increased the local 5-HT release $(n=4 ; p<0.000001)$ (Fig. $7 C)$. The time course of the 

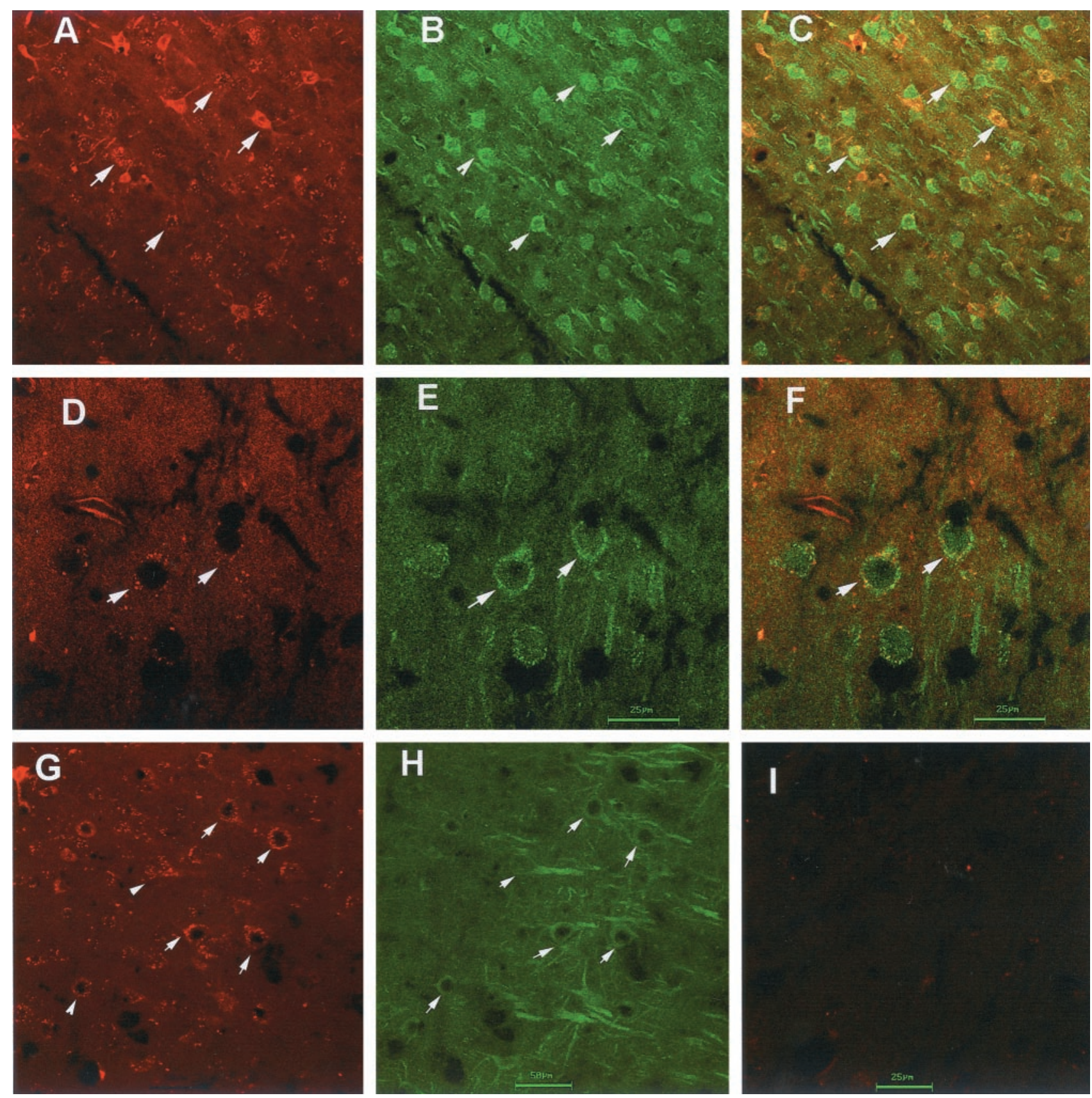

Figure 6. Colocalization of 5- $\mathrm{HT}_{2 \mathrm{~A}}$ and $5-\mathrm{HT}_{1 \mathrm{~A}}$ receptors in individual cortical neurons. $A$ shows a representative mPFC section depicting individual cortical neurons expressing 5- $\mathrm{HT}_{1 \mathrm{~A}}$-like immunoreactivity; $B$ shows the same section with $5-\mathrm{HT}_{2 \mathrm{~A}}$-like immunoreactivity; $C$ depicts an overlay showing colocalization of $5-\mathrm{HT}_{2 \mathrm{~A}}$ and $5-\mathrm{HT}_{1 \mathrm{~A}}$ receptor-like immunoreactivity in individual cortical neurons. Magnification, $400 \times . D$ shows a high-power $(1000 \times)$ view of individual cortical neurons expressing 5-HT $1 \mathrm{~A}$-like immunoreactivity; $E$ shows the same section with 5 - $\mathrm{HT}_{2 \mathrm{~A}}$-like immunoreactivity; $F$ depicts an overlay of 5- $\mathrm{HT}_{1 \mathrm{~A}}$ and 5- $\mathrm{HT}_{2 \mathrm{~A}}$ like immunoreactivity. $G$ shows a low-power $(400 \times)$ view of cortical neurons visualized with a guinea pig 5-HT $1 \mathrm{~A}$ receptor antibody, whereas $H$ shows the same section visualized with a monoclonal $5-\mathrm{HT}_{2 \mathrm{~A}}$ receptor antibody, with colocalization indicated by arrowheads. I shows a typical section incubated only with secondary antibodies $(400 \times)$.

effect differed from that elicited by AMPA (Fig. 4D) and showed a marked tachyphylaxis. However, the 5-HT increase was fully prevented by the coapplication of $300 \mu \mathrm{M} \mathrm{NBQX}(p<0.00005 \mathrm{vs}$ L-trans-PDC alone) (Fig. $7 C$ ) but not by $300 \mu \mathrm{M}$ MK-801, thus supporting the involvement of AMPA-KA receptors. The coapplication of $300 \mu \mathrm{M}$ cyclothiazide to prevent a putative desensitization of the glutamate receptors involved in this effect failed to modify the effect of L-trans-PDC, suggesting that the transient nature of the 5-HT increase was likely attributable to presynaptic adaptive mechanisms after glutamate uptake blockade.

\section{Effects of DOI on the firing rate of 5-HT neurons in the DR}

The systemic administration of DOI to chloral hydrateanesthetized rats induced a dose-dependent reduction of the firing rate of 5-HT neurons in the DR (Fig. 8). Two putative subgroups of neurons were identified, according to the maximal effect of DOI. In 7 of 12 neurons recorded, DOI fully suppressed the serotonergic activity at low doses. In the rest $(n=5)$, the effect of DOI on serotonergic cell firing was partial, with a 


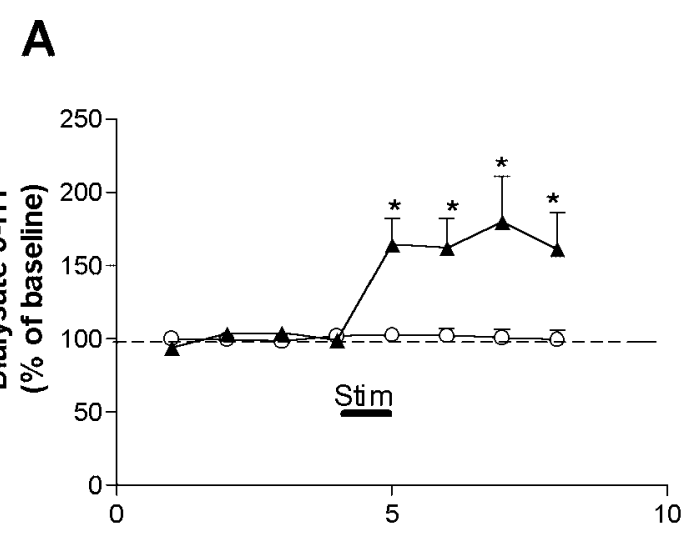

B
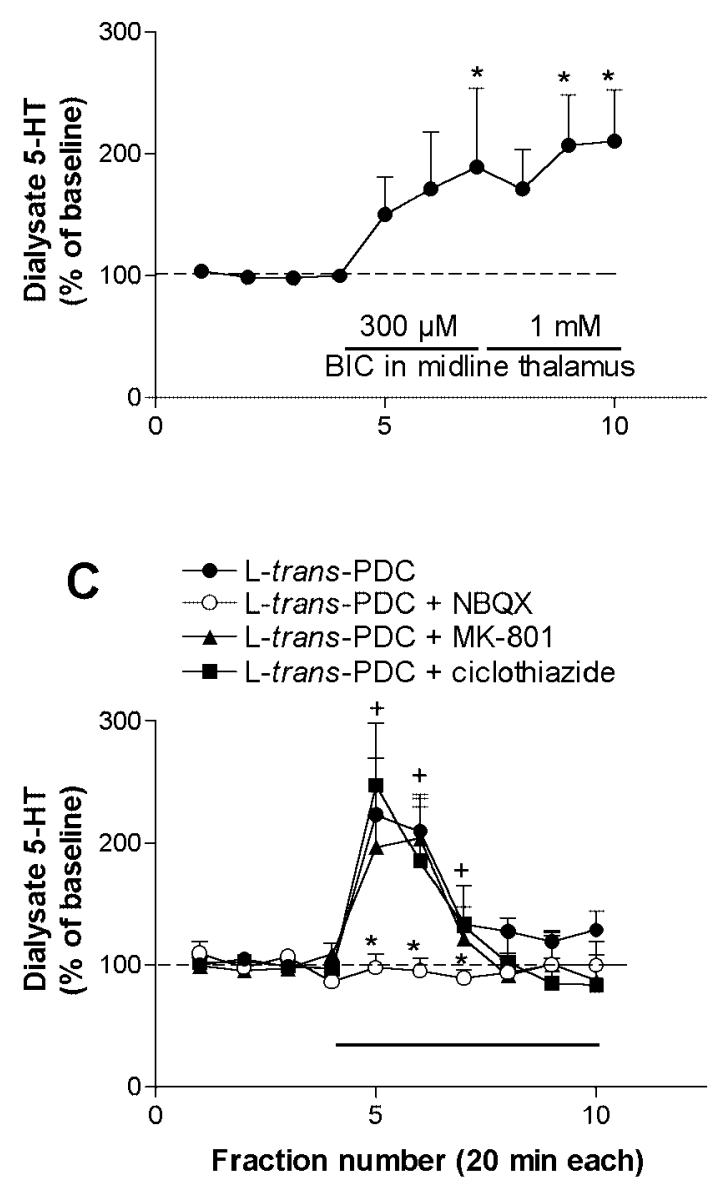

Figure 7. A, The electrical stimulation of a midline thalamic area affecting the mediodorsal nucleus and a small part of the centromedial nucleus ( $5 \mathrm{~Hz}, 1.5 \mathrm{~mA}, 0.3 \mathrm{msec}$ pulses; shown by a bar) for $20 \mathrm{~min}$ increased the 5-HT release in the mPFC of chloral hydrate-anesthetized rats (filled triangles; $n=6$ ). Control rats were implanted with microdialysis probes and thalamic electrodes, but no current was passed $(n=6$; open circles $)$. ${ }^{*} p<0.05$ versus baseline; Duncan test post-ANOVA. $B$, In dual probe microdialysis experiments, the application of bicuculline (BIC; $300 \mu \mathrm{M}$ and $1 \mathrm{mM}$, shown by a bar; $n=8$ ) by reverse dialysis in the centromedial and mediodorsal thalamic nuclei significantly increased the 5-HT release in $\mathrm{mPFC}$. The variability of the 5-HT increase was relatively large, possibly because of slight differences in the location of probes. ${ }^{*} p<0.05$ versus baseline; Duncan test post-ANOVA. $C$, Effects of the local application of the glutamate uptake inhibitor L-trans-PDC, alone or in combination with NBQX, MK-801, and cyclothiazide on the 5-HT release in maximal decrease to $\sim 40 \%$ of baseline. The administration of additional doses of DOI did not result in a further reduction. In some neurons, higher doses of DOI appeared to elicit a slight increase in firing rate, as shown in Figure $8 \mathrm{~B}$. In both subgroups, the effect of DOI was reversed by the administration of M100907 (100 $\mu \mathrm{g} / \mathrm{kg}$, i.v.) (Fig. 8B,D). The calculated $\mathrm{ED}_{50}$ value was 20 $\mu \mathrm{g} / \mathrm{kg}$ intravenously for all neurons (19 and $22 \mu \mathrm{g} / \mathrm{kg}$, i.v., for neurons with full and partial inhibitory response, respectively). When examined, the administration of the $5-\mathrm{HT}_{1 \mathrm{~A}}$ receptor agonist 8-OH-DPAT suppressed serotonergic cell firing in both subgroups of neurons (Fig. 8C,D). The further administration of WAY $100635(10 \mu \mathrm{g} / \mathrm{kg}$, i.v.) returned firing rate to baseline (Fig. $8 D)$. The inhibitory effect of DOI on serotonergic cell firing was also reversed by the administration of the $\mathrm{GABA}_{\mathrm{A}}$ receptor antagonist picrotoxinin (1 mg/kg, i.v.) (Fig. $8 E$ ).

To assess whether the increased mPFC release of 5-HT induced by local DOI application was caused by the activation of pyramidal neurons projecting to the DR (thus enhancing the activity of ascending 5-HT neurons), we locally infused DOI in the $\mathrm{mPFC}$ while recording $5-\mathrm{HT}$ neurons in the DR. In 5 of 10 serotonergic neurons in the DR, the application of DOI in $\mathrm{mPFC}$ (200 $\mu \mathrm{M}, 200 \mathrm{nl}$ applied in $1 \mathrm{~min}$ ) enhanced their firing rate (to $194 \pm 45 \%$ of baseline; range, $137-371 \%$; $p<0.02$ ) (Fig. 9A). One additional neuron had a marginal increase (115\% of baseline), and the rest were unaffected by the application of DOI in mPFC (Fig. 9B). The effects of a second dose of DOI (5 min after the first one) were examined in seven neurons. Of these, three responded with a further increase in DR firing (from 155 to $260 \%$ of baseline). The infusion of vehicle in mPFC did not affect the firing rate of DR 5-HT neurons (data not shown).

\section{Effect of the systemic administration of DOI on 5-HT release in medial prefrontal cortex}

The systemic administration of DOI ( $1 \mathrm{mg} / \mathrm{kg}$, s.c.) to chloral hydrate-anesthetized rats reduced the extracellular 5-HT concentration in the mPFC to a maximal effect of $33 \pm 8 \%$ of baseline $2 \mathrm{hr}$ after administration $(n=4 ; p<0.00001)$ (Fig. 10). The effect of DOI was reversed by the administration of M100907 (0.5 $\mathrm{mg} / \mathrm{kg}$, s.c.) which returned 5-HT levels to above baseline (127 \pm $6 \% ; p<0.00001$ ) (Fig. 10).

\section{DISCUSSION}

The present results show that the stimulation of $5-\mathrm{HT}_{2 \mathrm{~A}}$ receptors by the hallucinogen DOI markedly affects serotonergic transmission. Systemic DOI administration reduced the activity of DR 5-HT neurons and their release by mPFC terminals. Conversely, the selective activation of prefrontal $5-\mathrm{HT}_{2 \mathrm{~A}}$ receptors raised the local 5-HT release and the firing of a subgroup of 5-HT neurons.

Despite the low density of $5-\mathrm{HT}_{2 \mathrm{~A}}$ receptors in the $\mathrm{DR}$ and adjacent areas (Pompeiano et al., 1994; Fay and Kubin, 2000), bath application of 5-HT and DOI increased a $5-\mathrm{HT}_{2 \mathrm{~A}}$ receptordependent GABA input onto 5-HT neurons in midbrain slices

$\leftarrow$

mPFC ( $n=4-5)$. L-trans-PDC (4 mM) significantly increased the 5-HT release. This effect was prevented by the coperfusion of NBQX but not by MK-801 (300 $\mu \mathrm{M}$ each). Cyclothiazide $(300 \mu \mathrm{M})$, a drug that prevents the desensitization of AMPA receptors, did not affect the time course or potentiate the effect of L-trans-PDC, suggesting that the marked tachiphylaxis of the effect is possibly caused by a presynaptic adaptive change in glutamate synthesis and release resulting from prolonged inhibition of reuptake. ${ }^{+} p<0.05$ versus baseline; ${ }^{*} p<0.05$ versus L-trans-PDC alone; Duncan test post-ANOVA. 
A

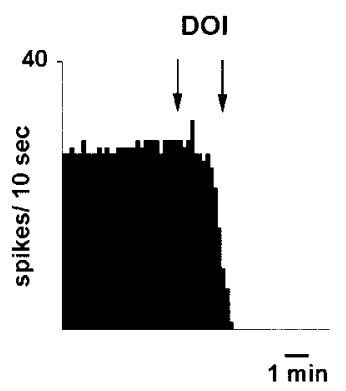

D

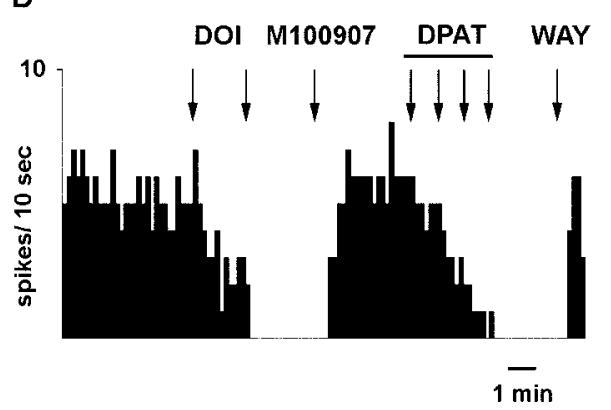

B

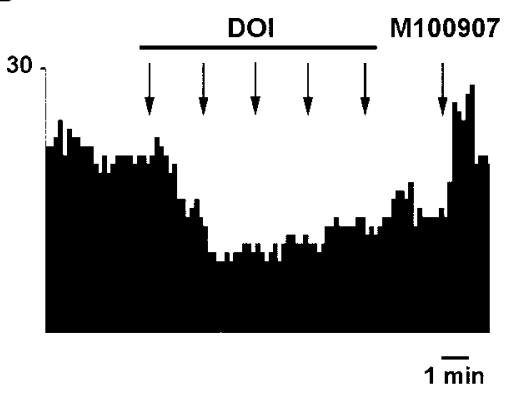

E

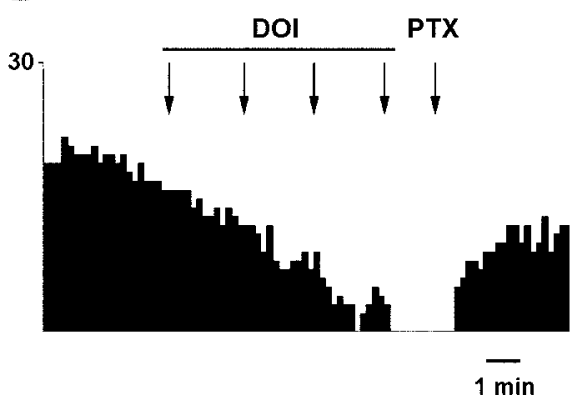

C

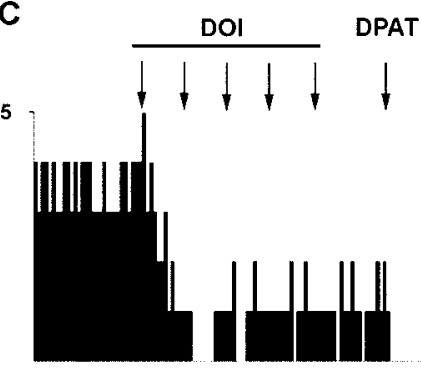

$1 \overline{\mathrm{min}}$

$\mathbf{F}$

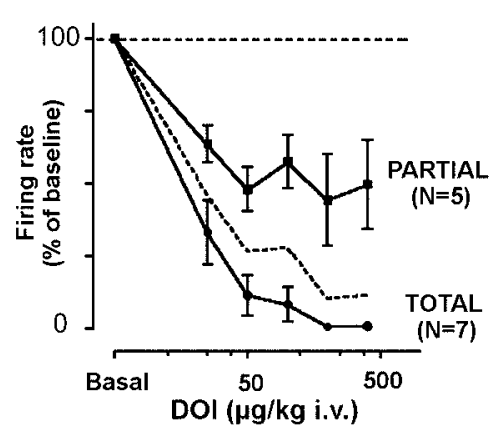

Figure 8. Effects of the intravenous administration of DOI on serotonergic neurons of the DR. $A-E$, Integrated firing rate histograms showing the effect of DOI on five different 5-HT neurons. $A-C$ depict neurons with full $(A)$ and partial $(B, C)$ inhibitory responses to the administration of cumulative doses of DOI $(25-50 \mu \mathrm{g} / \mathrm{kg}$, i.v. in $A ; 25-400 \mu \mathrm{g} / \mathrm{kg}$, i.v. in $B, C)$. The effect of DOI was antagonized by M100907 $(100 \mu \mathrm{g} / \mathrm{kg}$, i.v.; examples in $B$ and $D)$. The serotonergic nature of neurons with partial or full response to DOI is illustrated by its sensitivity to 8-OH-DPAT $(C, D)$. $D$ shows the inhibitory effect of DOI $(25-50 \mu \mathrm{g} / \mathrm{kg}$, i.v. $)$. After reversal by M100907 $(100 \mu \mathrm{g} / \mathrm{kg}$, i.v.), 8-OH-DPAT (DPAT; 0.25-2 $\mu \mathrm{g} / \mathrm{kg}$, i.v.) fully suppressed firing activity, and the $5-\mathrm{HT}_{1 \mathrm{~A}}$ receptor antagonist WAY 100635 (WAY; $10 \mu \mathrm{g} / \mathrm{kg}$, i.v.) returned firing rate to baseline. $E$ shows the reversal of the effect of DOI (25-200 $\mu \mathrm{g} / \mathrm{kg}$, i.v.) by the $\mathrm{GABA}_{\mathrm{A}}$ antagonist picrotoxinin (PTX; $1 \mathrm{mg} / \mathrm{kg}$, i.v.). The graph in $F$ shows the dose-response curves for DOI in 5-HT neurons. The neurons with partial and full inhibitory responses to DOI administration had comparable $\mathrm{ED}_{50}$ values $(19 \mathrm{and} 22 \mu \mathrm{g} / \mathrm{kg}$, i.v.; $n=7$ and 5 , respectively). The dotted line shows the dose-response curve for all neurons $(n=12)$.

A

25

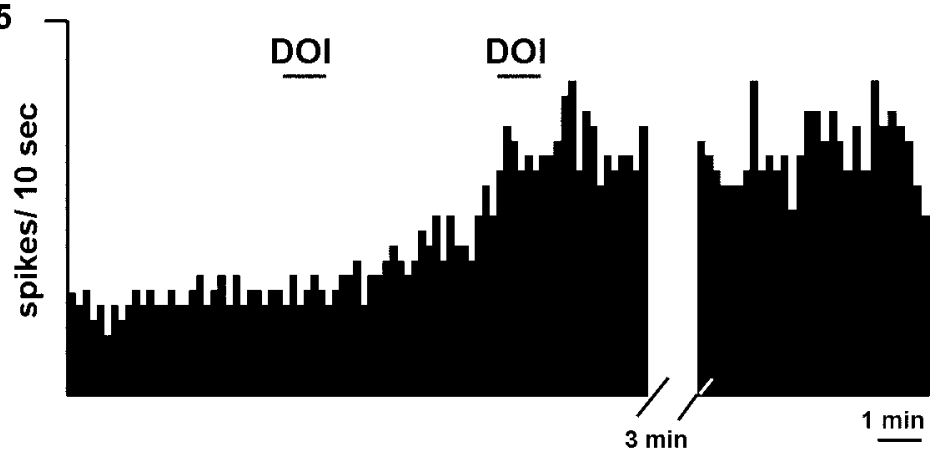

B

25

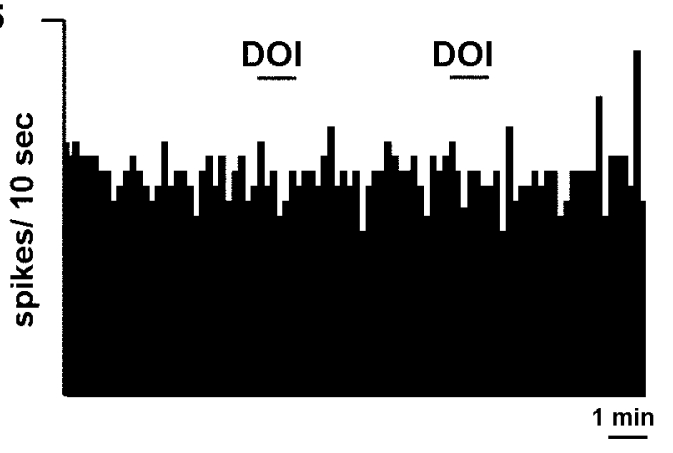

Figure 9. Integrated firing rate histograms of DR serotonergic neurons after the application of DOI in mPFC (200 $\mu \mathrm{M}, 200 \mathrm{nl}$, shown by a $1 \mathrm{~min}$ bar). The neuron in $A$ responded with an increase in firing rate after the first and second application of DOI (note the persistence of the increased firing rate), whereas the neuron in $B$ was unaffected by the application of two consecutive doses of DOI. The distal effect of DOI on 5-HT cell firing cannot be accounted for by drug diffusion to the DR because of the small amount of tissue affected by DOI application $(0.2 \mu \mathrm{l})$ and the inhibitory effect of DOI on 5-HT neurons when acting on DR 5- $\mathrm{HT}_{2 \mathrm{~A}}$ receptors (Liu et al., 2000).

(Liu et al., 2000). Thus, the activation by DOI of $5-\mathrm{HT}_{2 \mathrm{~A}}$ receptors on GABAergic afferents to 5-HT neurons might mediate its inhibitory effect on 5-HT neurons (Wright et al., 1990; Garratt et al., 1991; this work) inasmuch as the activation of prefrontal $5-\mathrm{HT}_{2 \mathrm{~A}}$ receptors induced the opposite effect. The involvement of $5-\mathrm{HT}_{2 \mathrm{~A}}$ and $\mathrm{GABA}_{\mathrm{A}}$ receptors in the DOI-induced inhibition of serotonergic cell firing is supported by the reversal induced by M100907 and picrotoxinin. Interestingly, DOI partially inhibited the firing activity of some 5-HT neurons, whereas fully sup- pressed other 5-HT neurons, with comparable $\mathrm{ED}_{50}$ values. This difference suggests either a partial agonist action of DOI or the involvement of two $5-\mathrm{HT}_{2 \mathrm{~A}}$ receptor populations (e.g., in midbrain and $\mathrm{mPFC}$ ) with opposed effects on the cell firing of some neurons.

Unlike its systemic administration (Wright et al., 1990; Gobert and Millan, 1999; this work) the local application of DOI enhanced the 5-HT release in $\mathrm{mPFC}$. We exclude a direct releasing action of DOI on serotonergic nerve endings (fenfluramine-like) 


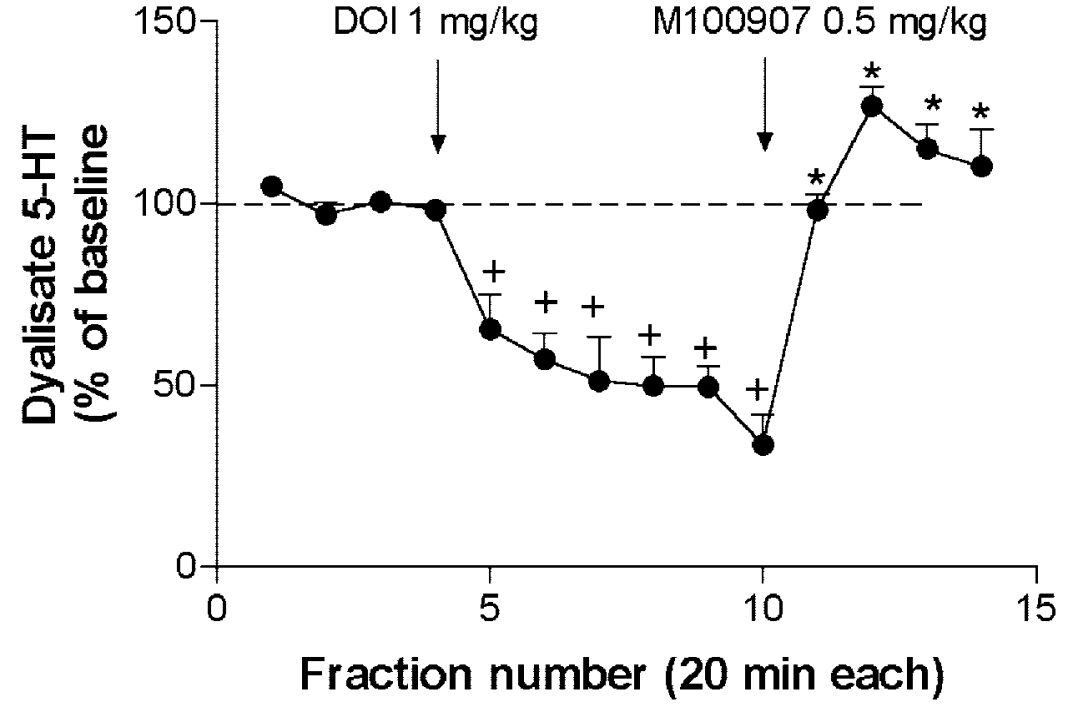

Figure 10. The systemic administration of DOI $(1 \mathrm{mg} / \mathrm{kg}$, s.c.) markedly reduced the 5-HT output in $\mathrm{mPFC}$ of chloral hydrate-anesthetized rats $(n=4)$. The selective 5 - $\mathrm{HT}_{2 \mathrm{~A}}$ receptor antagonist M100907 (0.5 mg/kg, s.c.) fully reversed the effect of DOI. Arrows mark injections. ${ }^{+} p<0.05$ versus baseline; ${ }^{*} p<0.05$ versus DOI alone; Duncan test post-ANOVA.

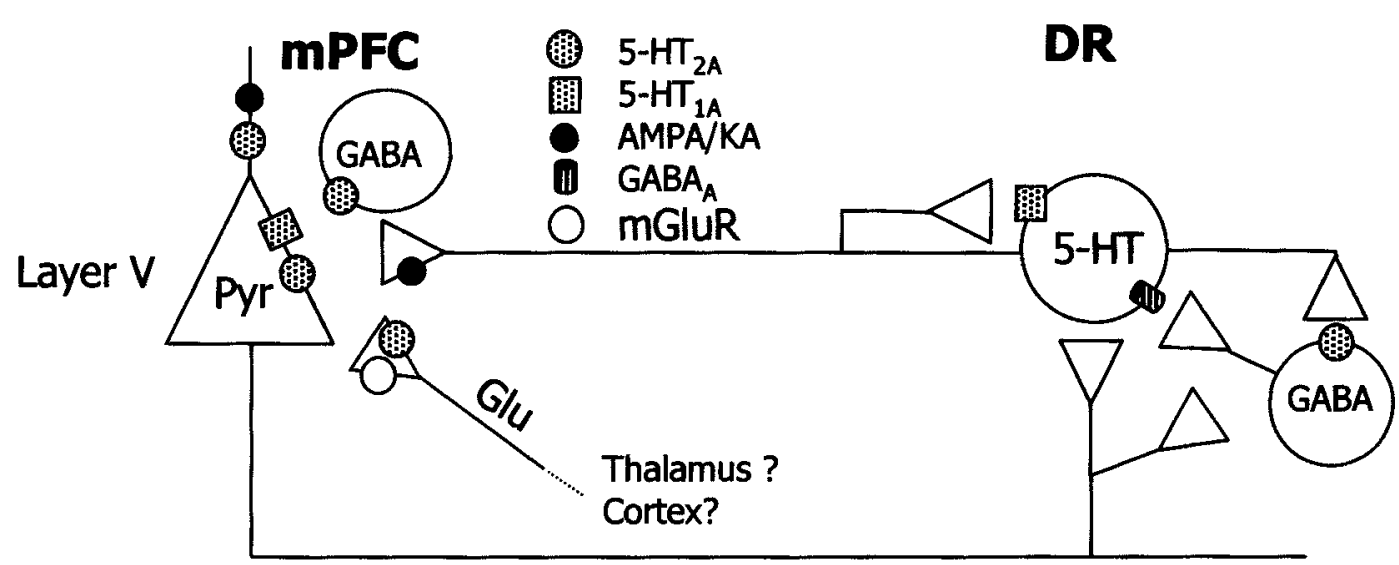

Figure 11. Scheme of the putative presynaptic and postsynaptic actions of DOI. In the mPFC, DOI increases 5-HT release. This effect involves the activation of prefrontal 5- $\mathrm{HT}_{2 \mathrm{~A}}$ receptors, possibly on glutamatergic afferents from midline thalamus. The role of 5- $\mathrm{HT}_{2 \mathrm{~A}}$ receptors on pyramidal neurons and GABA interneurons has not been elucidated. The activation of prefrontal 5- $\mathrm{HT}_{2 \mathrm{~A}}$ receptors enhances the release of glutamate, which acts on pyramidal AMPA receptors and increases impulse flow in layer $\mathrm{V}$ pyramidal neurons projecting to the DR, thus resulting in an increased serotonergic activity and 5-HT release in mPFC. Additionally, glutamate might activate terminal AMPA-KA receptors in 5-HT terminals and increase 5-HT release in a local manner. This might imply axo-axonic contacts between glutamatergic and serotonergic axons, not yet established anatomically but for which there is functional evidence (see Discussion). The activation of inhibitory 5- $\mathrm{HT}_{1 \mathrm{~A}}$ receptors on pyramidal neurons counteracts the effects of DOI and decreases 5-HT release, likely by reducing DOI excitatory effects on descending inputs to the DR, because the selective activation of prefrontal 5-HT $1 \mathrm{~A}$ receptors reduces the firing rate of DR 5-HT neurons (Celada et al., 2001). The firing-suppressant action of systemic DOI administration on DR 5-HT neurons is possibly accounted for by an action on local GABAergic elements inhibiting 5-HT neurons (Liu et al., 2000). This effect would also account for the inhibition of 5-HT release observed after systemic administration of DOI.

because this is insensitive to TTX (Carboni and Di Chiara, 1989). Moreover, 5-HT neurons do not express 5- $\mathrm{HT}_{2 \mathrm{~A}}$ receptors (Pompeiano et al., 1994; Fay and Kubin, 2000) (J. Serrats, R. Cortés, and G. Mengod, unpublished observations). Some cells in the DR (not known to be serotonergic) express $5-\mathrm{HT}_{2 \mathrm{C}}$ receptors (Clemett et al., 2000). However, the lack of antagonism by SB 242084 excludes the involvement of $5-\mathrm{HT}_{2 \mathrm{C}}$ receptors in the effect of DOI.

Several lines of evidence suggest that DOI increases the 5-HT release in $\mathrm{mPFC}$ indirectly, through the stimulation of glutamate release and subsequent activation of AMPA-KA receptors (Fig. 11). First, the 5-HT increase was reversed by NBQX but not by MK-801 and was mimicked by AMPA application. Second, several strategies aimed at increasing glutamatergic neurotransmission in the mPFC, such as the perfusion of the glutamate reuptake inhibitor L-trans-PDC (also enhancing striatal 5-HT release; Abellán et al., 2000) or the electrical-chemical stimula- tion of thalamic afferents to the mPFC elevated the 5-HT release. Third, as with DOI, the effect of L-trans-PDC was antagonized by NBQX but not by MK-801. Finally, the effect of DOI was reversed by the mGluR $2 / 3$ agonist $1 S, 3 S$-ACPD. The failure of the more selective agonist LY 379268 to counteract the DOI-induced 5-HT increase may be attributed to different in vivo pharmacological properties and/or involvement of other mGluR subtypes in the action of ACPD. Thus, LY 379268 increased 5-HT turnover and release in mPFC by itself (Cartmell et al., 2000, 2001), an effect that would oppose the expected reduction in 5-HT resulting from a decrease in glutamate. This difference warrants further investigation on the mGluR subtype involved in the control of 5-HT release in mPFC.

A critical step in the proposed mechanism is the actual assessment of the effect of DOI on glutamate release. However, extracellular glutamate concentrations are not representative of the 
transmitter-synaptic pool (Timmerman and Westerink, 1997) and depend to a large extent on a cysteine-glutamate exchanger (Baker and Kalivas, 2000). Our own data agree with this view, because extracellular glutamate was largely insensitive to manipulations known to alter synaptic transmission (M.V. Puig, A. Adell, P. Celada, and F. Artigas, unpublished observations).

The present results accord with previous in vitro work in MPFC slices showing that the activation of local $5-\mathrm{HT}_{2 \mathrm{~A}}$ receptors increases spontaneous EPSCs in layer V pyramidal neurons by an AMPA-dependent mechanism (Aghajanian and Marek, 1997, 1999b, 2000; Marek et al., 2000). However, none of these previous studies reported overt depolarization in pyramidal neurons by 5-HT or DOI. In contrast, we observed that the stimulation of $5-\mathrm{HT}_{2 \mathrm{~A}}$ receptors in $\mathrm{mPFC}$ by DOI increased the firing of identified 5-HT neurons in the DR. Likewise, in pilot experiments, systemic DOI administration activated projection neurons in the mPFC (Puig, Celada, and Artigas, unpublished observations). This strongly suggests that DOI increases impulse flow in pyramidal neurons, including those projecting to the DR. The discrepancy between the present results and those of Aghajanian and Marek (2000) may be attributable to methodological differences, perhaps reflecting the loss of active glutamatergic inputs in the slice preparation used by these authors.

The cellular source or sources of glutamate and the precise localization or localizations of $5-\mathrm{HT}_{2 \mathrm{~A}}$ receptors accounting for this effect are debated. $5-\mathrm{HT}_{2 \mathrm{~A}}$ receptors occur in three different populations in frontal cortex: pyramidal neurons (major $5-\mathrm{HT}_{2 \mathrm{~A}^{-}}$ containing neurons), GABAergic interneurons, and axon terminals (Willins et al., 1997; Jakab and Goldman-Rakic, 1998, 2000; $\mathrm{Xu}$ and Pandey, 2000). Layer V contains the somata of pyramidal neurons and dense bundles of apical dendrites, highly enriched in 5- $\mathrm{HT}_{2 \mathrm{~A}}$ receptors (Willins et al., 1997; Jakab and GoldmanRakic, 1998; Xu and Pandey, 2000) (Fig. 6). GABA interneurons are the main target of 5-HT terminals in monkey prefrontal cortex (Smiley and Goldman-Rakic, 1996) and DOI increases extracellular GABA in rat brain (Abi-Saab et al., 1999). However, $5-\mathrm{HT}_{2 \mathrm{~A}}$ receptors on thalamic afferents have been suggested to mediate DOI effects. Hence, $\mu$-opioid agonists and lesions of the medial thalamus attenuated the 5-HT-induced EPSCs in layer V pyramidal neurons (Marek and Aghajanian, 1998; Marek et al., 2001), which suggests a presynaptic site of action. Moreover, the systemic administration of DOI increased Fos expression in superficial layer $\mathrm{V}$ and above, an effect also dependent on the integrity of thalamic inputs onto mPFC (Scruggs et al., 2000). However, most Fos-expressing neurons were nonpyramidal, whereas 5-HT induces spontaneous EPSCs in layer V pyramidal neurons by activation of $5-\mathrm{HT}_{2 \mathrm{~A}}$ receptors (Lambe et al., 2000), which makes uncertain the relationship between both observations. The present data suggest that glutamate from thalamic afferents to $\mathrm{mPFC}$ enhances 5-HT release, although it remains to be determined whether this is the glutamate source involved in the local DOI effects.

Indeed, a preferential action of DOI on terminal $5-\mathrm{HT}_{2 \mathrm{~A}}$ receptors would leave the dense population of pyramidal $5-\mathrm{HT}_{2 \mathrm{~A}}$ receptors without a significant role. Interestingly, the DOIinduced increase in 5-HT release was potently counteracted by coperfusion of the selective $5-\mathrm{HT}_{1 \mathrm{~A}}$ receptor agonist $\mathrm{BAY} \times$ 3702. $5-\mathrm{HT}_{1 \mathrm{~A}}$ and $5-\mathrm{HT}_{2 \mathrm{~A}}$ receptors colocalize on cortical pyramidal neurons (Fig. $6 A-I$ ) and have opposite effects on their excitability (Araneda and Andrade, 1991). The apparent absence of 5- $\mathrm{HT}_{1 \mathrm{~A}}$ receptors on 5-HT terminals (Pompeiano et al., 1992; Kia et al., 1996) excludes a presynaptic action of BAY $\times 3702$.
Pyramidal neurons in $\mathrm{mPFC}$ project to and control the activity of DR 5-HT neurons (see introductory remarks). Thus, DOI and BAY $\times 3702$ may modulate the release of 5 -HT in mPFC by increasing and decreasing, respectively, the activity of descending excitatory pathways to DR neurons projecting in turn to the mPFC (Fig. 11). Thus, the application of DOI and 8-OH-DPAT in $\mathrm{mPFC}$ increased and decreased, respectively, the firing rate of DR 5-HT cells (Celada et al., 2001; this work). However, the present study cannot determine whether the effect of DOI on pyramidal activity is direct (via pyramidal $5-\mathrm{HT}_{2 \mathrm{~A}}$ receptors) or indirect (via terminal $5-\mathrm{HT}_{2 \mathrm{~A}}$ receptors, increase in glutamate and activation of AMPA receptors on pyramidal neurons) (Fig. 11). Additionally, the activation of terminal AMPA receptors increases transmitter release in vivo and in vitro (Ohta et al., 1994; Whitton et al., 1994; Maione et al., 1997, Tao et al., 1997; Lockhart et al., 2000). This raises the possibility that a second (local) mechanism may also modulate 5-HT release independently of DR activation.

$5-\mathrm{HT}_{2 \mathrm{~A}}$ receptors play a crucial role in the filtering of inputs reaching the somata of pyramidal neurons because their activation increases neuronal excitability. The activation by DOI of prefrontal $5-\mathrm{HT}_{2 \mathrm{~A}}$ receptors increases the excitability of pyramidal neurons. At the same time, its action on (possibly) midbrain $5-\mathrm{HT}_{2 \mathrm{~A}}$ receptors (Liu et al., 2000) reduces 5-HT cell firing and 5-HT release, which should result in a diminished activation of inhibitory pyramidal $5-\mathrm{HT}_{1 \mathrm{~A}}$ receptors. Hence, the net balance of both effects would be an increased firing activity of projection neurons in layer V, as preliminarily observed (Puig, Celada, and Artigas, unpublished observations). This effect may mediate the hallucinogenic action of DOI. Hence, the blockade of $5-\mathrm{HT}_{2 \mathrm{~A}}$ receptors or the direct or functional 5- $\mathrm{HT}_{1 \mathrm{~A}}$ receptor agonism exerted by atypical antipsychotics (Meltzer, 1999; Ichikawa et al., 2001) might be viewed as an attempt to restore the physiological balance between excitatory and inhibitory inputs onto prefrontal pyramidal neurons. Given the opposing roles of $5-\mathrm{HT}_{1 \mathrm{~A}}$ and $5-\mathrm{HT}_{2 \mathrm{~A}}$ receptors on the output of layer $\mathrm{V}$ pyramidal neurons, compounds with $5-\mathrm{HT}_{2 \mathrm{~A}}$ antagonism and 5-HT $\mathrm{H}_{1 \mathrm{~A}}$ agonism may be particularly useful to treat hallucinations and, more generally, positive symptoms in schizophrenia. Likewise, their direct action at $5-\mathrm{HT}_{1 \mathrm{~A}}$ receptors might also improve negative (deficit) symptoms.

Further work is required to clarify the relative role of local and distal mechanisms in the control of 5-HT release by prefrontal $5-\mathrm{HT}_{1 \mathrm{~A} / 2 \mathrm{~A}}$ receptors and the precise localization of $5-\mathrm{HT}_{2 \mathrm{~A}}$ receptors responsible for this effect of DOI.

\section{REFERENCES}

Abellán MT, Martín-Ruiz R, Artigas F (2000) Local modulation of the 5 -HT release in the dorsal striatum of the rat. An in vivo microdialysis study. Eur Neuropsychopharmacol 10:455-462.

Abi-Saab W M, Bubser M, Roth RH, Deutch AY (1999) 5-HT 2 receptor regulation of extracellular GABA levels in the prefrontal cortex. Neuropsychopharmacology 20:92-96.

Adell A, Artigas F (1998) A microdialysis study of the in vivo release of 5 -HT in the median raphe nucleus of the rat. $\mathrm{Br} \mathrm{J}$ Pharmacol 125:1361-1367.

Aghajanian GK, Marek GJ (1997) Serotonin induces excitatory postsynaptic potentials in apical dendrites of neocortical pyramidal cells. Neuropharmacology 36:589-599.

Aghajanian GK, Marek GJ (1999a) Serotonin, via 5- $\mathrm{HT}_{2 \mathrm{~A}}$ receptors, increases EPSCs in layer v pyramidal cells of prefrontal cortex by an asynchronous mode of glutamate release. Brain Res 825:161-171.

Aghajanian GK, Marek GJ (1999b) Serotonin-glutamate interactions: A new target for antipsychotic drugs. Neuropsychopharmacology 21:S122-S133.

Aghajanian GK, Marek GJ (2000) Serotonin model of schizophrenia: emerging role of glutamate mechanisms. Brain Res Rev 31:302-312.

Aghajanian GK, Wang RY (1977) Habenular and other midbrain raphe 
afferents demonstrated by a modified retrograde tracing technique. Brain Res 122:229-242.

Araneda R, Andrade R (1991) 5-Hydroxytryptamine 2 and 5-hydroxytryptamine $_{1 \mathrm{~A}}$ receptors mediate opposing responses on membrane excitability in rat association cortex. Neuroscience 40:399-412.

Azmitia EC, Segal M (1978) An autoradiographic analysis of the differential ascending projections of the dorsal and median raphe nuclei in the rat. J Comp Neurol 179:641-668.

Baker DA, Kalivas PW (2000) Cocaine-induced alterations in extracellular glutamate levels: role of cystine/glutamate exchange. Soc Neurosci Abstr 26:792.

Berry SA, Shah MC, Khan N, Roth BL (1996) Rapid agonist-induced internalization of 5-hydroxytryptamine $2 \mathrm{~A}$ receptors occurs via the endosome pathway in vitro. Mol Pharmacol 50:306-313.

Carboni E, Di Chiara G (1989) Serotonin release estimated by transcortical dialysis in freely-moving animals. Neuroscience 32:637-645.

Cartmell J, Salhoff CR, Perry KW, Monn JA, Schoepp DD (2000) Dopamine and 5-HT turnover are increased by the $\mathrm{mGlu} 2 / 3$ receptor agonist LY379268 in rat medial prefrontal cortex, nucleus accumbens and striatum. Brain Res 887:378-834

Cartmell J, Perry KW, Salhoff CR, Monn JA, Schoepp DD (2001) Acute increases in monoamine release in the rat prefrontal cortex by the mGlu2/3 agonist LY379268 are similar in profile to risperidone, not locally mediated, and can be elicited in the presence of uptake blockade. Neuropharmacology 40:847-855.

Casanovas JM, Hervás I, Artigas F (1999) Postsynaptic 5-HT 1 A receptors control 5-HT release in the rat medial prefrontal cortex. NeuroReport 10:1441-1445.

Casanovas JM, Berton O, Celada P, Artigas F (2000) In vivo actions of the selective $5-\mathrm{HT}_{1 \mathrm{~A}}$ receptor agonist BAY x 3702 on serotonergic cell firing and release. Naunyn Schmiedebergs Arch Pharmacol 362:248-254.

Celada P, Siuciak JA, Tran TM, Altar CA, Tepper JM (1996) Local infusion of brain-derived neurotrophic factor modifies the firing pattern of dorsal raphe serotonergic neurons. Brain Res 712:293-298.

Celada P, Puig MV, Casanovas JM, Guillazo G, Artigas F (2001) Control of dorsal raphe serotoninergic neurons by the medial prefrontal cortex: role of $5-\mathrm{HT}_{1 \mathrm{~A}} \mathrm{GABA}$ and glutamate receptors. J Neurosci 21:9917-9929.

Clemett DA, Punhani T, Duxon MS, Blackburn TP, Fone KC (2000) Immunohistochemical localisation of the $5-\mathrm{HT}_{2 \mathrm{C}}$ receptor protein in the rat CNS. Neuropharmacology 39:123-132.

De Vry J, Schohe-Loop R, Heine HG, Greuel JM, Mauler F, Schmidt B, Sommermeyer H, Glaser T (1998) Characterization of the aminomethylchroman derivative BAY x 3702 as a highly potent 5-hydroxytryptamine(1A) receptor agonist. J Pharmacol Exp Ther 284:1082-1094.

Fay R, Kubin L (2000) Pontomedullary distribution of 5- $\mathrm{HT}_{2 \mathrm{~A}}$ receptorlike protein in the rat. J Comp Neurol 418:323-345.

Fuster JM (1997) The prefrontal cortex. Anatomy, physiology and neuropsychology of the frontal Lobe. New York: Lippincott-Raven.

Garratt JC, Kidd EJ, Wright IK, Marsden CA (1991) Inhibition of 5-hydroxytryptamine neuronal activity by the 5-HT agonist, DOI. Eur J Pharmacol 199:349-355.

Gobert A, Millan MJ (1999) Serotonin (5-HT)2A receptor activation enhances dialysate levels of dopamine and noradrenaline, but not 5 -HT, in the frontal cortex of freely-moving rats. Neuropharmacology 38:315-317

Haddjeri N, de Montigny C, Blier P (1999) Modulation of the firing activity of rat serotonin and noradrenaline neurons by $(+/-)$ pindolol. Biol Psychiatry 45:1163-1169.

Hajós M, Richards CD, Szekely AD, Sharp T (1998) An electrophysiological and neuroanatomical study of the medial prefrontal cortical projection to the midbrain raphe nuclei in the rat. Neuroscience 87:95-108.

Ichikawa J, Ishii H, Bonaccorso S, Fowler WL, O'Laughlin IA, Meltzer HY (2001) 5-HT ${ }_{2 \mathrm{~A}}$ and D-2 receptor blockade increases cortical DA release via $5-\mathrm{HT}_{1 \mathrm{~A}}$ receptor activation: a possible mechanism of atypical antipsychotic-induced cortical dopamine release. J Neurochem 76:1521-1531.

Jakab RL, Goldman-Rakic PS (1998) 5-Hydroxytryptamine 2 serotonin receptors in the primate cerebral cortex: possible site of action of hallucinogenic and antipsychotic drugs in pyramidal cell apical dendrites. Proc Natl Acad Sci USA 95:735-740.

Jakab RL, Goldman-Rakic PS (2000) Segregation of serotonin 5- $\mathrm{HT}_{2 \mathrm{~A}}$ and $5-\mathrm{HT}_{3}$ receptors in inhibitory circuits of the primate cerebral cortex. J Comp Neurol 417:337-348.

Kia HK, Miquel MC, Brisorgueil MJ, Daval G, Riad M, El Mestikawy S, Hamon M, Vergé D (1996) Immunocytochemical localization of serotonin(1A) receptors in the rat central nervous system. J Comp Neurol 365:289-305.

Kroeze WK, Roth BL (1998) The molecular biology of serotonin receptors: therapeutic implications for the interface of mood disorders and psychosis. Biol Psychiatry 44:1128-1142.

Lambe EK, Goldman-Rakic PS, Aghajanian GK (2000) Serotonin induces EPSCs preferentially in layer V pyramidal neurons of the frontal cortex in the rat. Cereb Cortex 10:974-980.
Liu RJ, Jolas T, Aghajanian GK (2000) Serotonin 5-HT 2 receptors activate local GABA inhibitory inputs to serotonergic neurons of the dorsal raphe nucleus. Brain Res 873:34-45.

Lockhart B, Iop F, Closier M, Lestage P (2000) (S)-2,3-dihydro-[3,4]cyclopentano-1,2,4-benzothiadiazine-1,1-dioxide: (S18986-1) a positive modulator of AMPA receptors enhances $(S)$-AMPA-mediated $\left[{ }^{3} \mathrm{H}\right]$ noradrenaline release from rat hippocampal and frontal cortex slices. Eur J Pharmacol 401:145-153.

Maione S, Rossi F, Biggs CS, Fowler LJ, Whitton PS (1997) AMPA receptors modulate extracellular 5-hydroxytryptamine concentration and metabolism in rat striatum in vivo. Neurochem Int 30:299-304.

Marek GJ, Aghajanian GK (1998) 5-hydroxytryptamine-induced excitatory postsynaptic currents in neocortical layer $\mathrm{v}$ pyramidal cells: suppression by $\mu$-opiate receptor activation. Neuroscience 86:485-497.

Marek GJ, Wright RA, Gewitz JC, Schoepp DD (2001) A major role for thalamocortical afferents in serotonergic hallucinogen receptor function in neocortex. Neuroscience 105:379-392.

Marek GJ, Wright RA, Schoepp DD, Monn JA, Aghajanian GK (2000) Physiological antagonism between 5-hydroxytryptamine (2A) and group II metabotropic glutamate receptors in prefrontal cortex. J Pharmacol Exp Ther 292:76-87.

Meltzer HY (1999) The role of serotonin in antipsychotic drug action. Neuropsychopharmacology 21:S106-S115.

Myers RD (1971) Methods for chemical stimulation of the brain. In: Methods of psychobiology, Vol 1 (Myers RD, ed), pp 247-280. New York: Academic.

Ohta K, Fukuuchi Y, Shimazu K, Komatsumoto S, Ichijo M, Araki N, Shibata M (1994) Presynaptic glutamate receptors facilitate release of norepinephrine and 5-hydroxytryptamine as well as dopamine in the normal and ischemic striatum. J Auton Nerv Syst 49:S195-S202.

Paxinos G, Watson C (1986) The rat brain in stereotaxic coordinates. Sydney: Academic.

Peyron C, Petit JM, Rampon C, Jouvet M, Luppi PH (1998) Forebrain afferents to the rat dorsal raphe nucleus demonstrated by retrograde and anterograde tracing methods. Neuroscience 82:443-468.

Pompeiano M, Palacios JM, Mengod G (1992) Distribution and cellular localization of mRNA coding for $5-\mathrm{HT}_{1 \mathrm{~A}}$ receptor in the rat brain: correlation with receptor binding. J Neurosci 12:440-453.

Pompeiano M, Palacios JM, Mengod G (1994) Distribution of the serotonin $5-\mathrm{HT}_{2}$ receptor family mRNAs: comparison between $5-\mathrm{HT}_{2 \mathrm{~A}}$ and 5- $\mathrm{HT}_{2 \mathrm{C}}$ receptors. Mol Brain Res 23:163-178.

Robbins TW (2000) Chemical neuromodulation of frontal-executive functions in humans and other animals. Exp Brain Res 133:130-138.

Sawyer SF, Tepper JM, Young SJ, Groves PM (1985) Antidromic activation of dorsal raphe neurons from neostriatum: physiological characterization and effects of terminal autoreceptor activation. Brain Res 332:15-28.

Scruggs JL, Patel S, Bubser M, Deutch AY (2000) DOI-Induced activation of the cortex: dependence on $5-\mathrm{HT}_{2 \mathrm{~A}}$ heteroceptors on thalamocortical glutamatergic neurons. J Neurosci 20:846-852.

Sesack SR, Deutch AY, Roth RH, Bunney BS (1989) Topographical organization of the efferent projections of the medial prefrontal cortex in the rat: an anterograde tract-tracing study with Phaseolus vulgaris leucoagglutinin. J Comp Neurol 290:213-242.

Smiley JF, Goldman-Rakic PS (1996) Serotonergic axons in monkey prefrontal cerebral cortex synapse predominantly on interneurons as demonstrated by serial section electron microscopy. J Comp Neurol 367:431-443.

Tao R, Ma Z, Auerbach SB (1997) Influence of AMPA/kainate receptors on extracellular 5-hydroxytryptamine in rat midbrain raphe and forebrain Br J Pharmacol 121:1707-1715.

Timmerman W, Westerink BHC (1997) Brain microdialysis of GABA and glutamate: what does it signify? Synapse 27:242-261.

Wang RY, Aghajanian GK (1977) Antidromically identified serotonergic neurons in the rat midbrain raphe: evidence for collateral inhibition. Brain Res 132:186-193.

Whitton PS, Maione S, Biggs CS, Fowler LJ (1994) Tonic desensitization of hippocampal alpha-amino-3-hydroxy-5-methyl-4-isoxazolepropionic acid receptors regulates 5-hydroxytryptamine release in vivo. Neuroscience 63:945-948.

Willins DL, Deutch AY, Roth BL (1997) Serotonin $5 \mathrm{HT}_{2 \mathrm{~A}}$ receptors are expressed on pyramidal neurons and interneurons in the rat cortex. Synapse 27:79-82

Willins DL, Berry SA, Alsayegh L, Backstrom JR, Sanders-Bush E, Friedman L, Roth BL (1999) Clozapine and other 5-hydroxytryptamine-2A receptor antagonists alter the subcellular distribution of 5 -hydroxytryptamine-2A receptors in vitro and in vivo. Neuroscience 91:599-606.

Wright IK, Garratt JC, Marsden CA (1990) Effects of a selective 5-HT agonist, DOI, on 5-HT neuronal firing in the dorsal raphe nucleus and 5-HT release and metabolism in the frontal cortex. Br J Pharmacol 99:221-222.

$\mathrm{Xu}$ TJ, Pandey SC (2000) Cellular localization of $\operatorname{serotonin}_{2 \mathrm{~A}}\left(5 \mathrm{HT}_{2 \mathrm{~A}}\right)$ receptors in the rat brain. Brain Res Bull 51:499-505. 